\title{
How the provision of childcare affects attitudes towards maternal employment
}

Anja Roth

\begin{abstract}
Do childcare institutions affect gender norms of individuals? I examine the introduction of childcare services and their impact on voters' support of policies promoting maternal employment. I address the inherent endogeneity between institutions and attitudes by exploiting regional variation in the regulations and provision of childcare for school children outside of regular school hours. My results show that the expansion of childcare for school children increases voters' support of policies promoting maternal employment. This indicates a direct effect of local institutions on voters' attitudes. I additionally show that as public costs of the new facilities increase, support of additional policies promoting maternal employment decreases.
\end{abstract}

Keywords: Childcare, Gender norms, Maternal employment, Policy evaluation

JEL classifications: $\mathrm{H} 23 ; \mathrm{H} 31 ; \mathrm{J} 13 ; \mathrm{J} 18$

\section{Introduction}

Promoting female employment has been an important goal of most developed countries over the past decades. Despite large advances in women's educational attainment and labor market attachment, there is still a striking divergence in earnings' paths of women and men following the birth of a child. Kleven et al. (2019) show that women's earnings decrease by 30\% (Denmark) to $80 \%$ (Germany) after the birth of the first child and remain $20 \%$ respectively $60 \%$ below their counterfactual income 10 years after the birth of their first child. Men's incomes, on the other hand, remain largely unaffected by the birth of a child ${ }^{1}$. Parental leave and public childcare decrease the costs for parents to remain attached to the labor market and have been seen as the most important

\footnotetext{
${ }^{1}$ Studies on the impact of childbirth on earnings patterns and on the role of parenthood in explaining gender gaps are e.g. (Adda et al. 2017; Angelov et al. 2016; Bertrand et al. 2010; Bütikofer et al. 2018; Budig and England 2001; Correll et al. 2007; Felfe 2012; Fitzenberger et al. 2013; Goldin 2014; Kleven et al. 2019; Paull 2008; Waldfogel 1998).
}

Correspondence: anja.roth@unibas.ch.

University of Basel, Faculty of Business and Economics, Peter Merian-Weg 6 4002 Basel, Switzerland instruments in allowing parents to reconcile work and family responsibilities ${ }^{2}$.

Recent evidence suggests that gender attitudes are an important factor in explaining the large differences in the decrease in female earnings across countries following the birth of a child (Kleven et al. 2019): Female earnings' decreases following the birth of a first child are smaller in countries with more positive attitudes towards working mothers. Given these findings, it is crucial to understand the formation of gender attitudes and to disentangle the inherent endogeneity between gender attitudes and institutions facilitating maternal employment.

This paper offers an empirical analysis of whether childcare institutions affect political attitudes towards policies facilitating the conciliation of work and family responsibilities. It benefits from a quasi-experimental setting in Switzerland, which creates discontinuity in regulations and in the actual provision of lunchtime and after-school care and thus allows for the application of a differences-indifferences strategy. It also benefits from federal ballots on family policy related topics revealing voters' preferences.

\footnotetext{
${ }^{2}$ Olivetti and Petrongolo (2017) give an excellent overview of family policies across high-income countries and effects of parental leave and early childhood education and care on female employment rates, the gender employment gap, gender earnings gap, and fertility rates.
} 
In 2010, the cantons of Bern and Zurich introduced a new regulation requiring municipalities to assess the demand for childcare for school children each year and to introduce lunchtime and after-school care in case of sufficient demand. Using municipalities in neighboring cantons as a control group allows me to apply a differences-in-differences design to estimate the effect of this new regulation on individuals' attitudes. The regulation additionally creates interesting variation within cantons, which allows me to study the effect of the actual provision of lunchtime and after-school care on individuals' attitudes towards working mothers: The regulation clearly states that if ten or more children are signed up for lunchtime and after-school care, the municipality is obligated to introduce these facilities. There are thus some municipalities which are required to introduce lunchtime and after-school care as a consequence of the new regulation, while others are not. I also exploit this feature for the analysis within the same differences-in-differences estimation.

The variation within and across cantons allows me to isolate the effect of the introduction of lunchtime and after-school care from the effect of the public costs arising from the expansion of childcare facilities. The total public costs of lunchtime and after-school care are borne by all municipalities within the cantons with regulation, and not only municipalities which introduce lunchtime and after-school care. Estimating the two treatment margins, the provision margin and the regulation margin, isolates the two effects. The cost effect is estimated by comparing municipalities within the treated cantons but without provision to municipalities in the untreated cantons. The provision effect estimates the change in voter support in municipalities with and without provision but within the cantons with regulation. This empirical approach relies on parallel trends of all three types of municipalities: municipalities with no regulation and no provision, municipalities with regulation but no provision, and municipalities with regulation and provision. These identifying assumptions are discussed in more detail in Section 3 and challenged drawing upon vote results of bills voted upon on the same day as family policy related bills and individual level post-vote survey data on family policy related bills. Furthermore, drawing on a large number of ballots on healthcare-related topics voted upon in the same time period considered for the main analysis allows me to show that the three groups of municipalities, municipalities in cantons with no regulation, municipalities in cantons with regulation and no provision, and municipalities in cantons with regulation and provision, do not generally show diverging trends, thus affirming my identifying assumptions. I find that the introduction of lunchtime and after-school care increases support for policies promoting maternal employment by up to 3 percentage points compared to support in municipalities with no provision of lunchtime and after-school care but otherwise within the same institutional framework. Furthermore, I find a larger effect in municipalities where public costs of the new facilities are low. Controlling for the actual provision allows for an estimation of the pure cost effect, hereafter termed regulation effect. I find a negative effect of the regulation, with support of public policies promoting maternal employment decreasing by up to 10 percentage points. This is in line with the finding that the increase in support is larger when costs are lower. While I cannot fully reject the hypothesis that the positive shift in political attitudes is purely driven by parents directly benefitting from such policies, this seems unlikely to be the case. I put forward suggestive evidence showing that the change in approval rates of parents in the treated cantons does not differ from changes in approval rates of the remaining population, and that the change in approval rates is driven by a change in preferences for policies promoting gender equality.

This paper contributes to the literature focusing on the impact of institutions on gender attitudes and expands on it by focusing on the very short-term effect of childcare institutions on vote outcomes reflecting gender attitudes. Slotwinski and Stutzer (2018) show that the introduction of female suffrage leads to substantial changes in individuals' norms and outcomes even in the medium term. Exploiting the German separation and later reunification, Bauernschuster and Rainer (2012) show that individuals exposed to East German institutions promoting female employment hold more equal gender attitudes than West Germans after reunification. Unterhofer and Wrohlich (2017) study a parental leave reform in Germany in 2007, which introduced the option for fathers to take part of the parental leave, and its effect on grandparents' attitudes. They find that mothers of exposed fathers have significantly more positive attitudes towards working mothers but find no effect for fathers. Their study shows that there is a short term effect of institutions on attitudes of individuals in the immediate environment and in the very short term.

This study is further related to a paper by Felfe et al. (2016), who also exploit the introduction of the same regulation and its effect on parents' employment. However, they only have cross sectional data on childcare provision and employ an IV strategy using the regulation I exploit as an instrument. They find that the introduction of lunchtime and after-school care increases maternal fulltime employment, with no effect on fathers and no change in participation rates. I apply a different empirical design since I have to control for level differences between the treated and control groups, which they cannot do in their setting. 
The rest of the paper has the following structure. The next section provides information on the institutional background serving as a backdrop to this analysis and demonstrates how vote outcomes are an interesting approach to measuring attitudes. Section 3 contains the main theoretical considerations and the empirical identification strategy. Section 4 presents the data, some descriptive statistics, and graphical depiction of preliminary results. Section 5 presents the empirical results. Section 6 discusses the costs of public institutions as a potential mechanism driving the results and presents some robustness analyses. Section 7 concludes.

\section{Institutional background}

In Switzerland, life cycle employment patterns differ strongly between genders and are largely shaped by children $^{3}$. While female labor force participation has steadily been increasing since 1980 and is now among the highest of OECD countries, women's weekly hours are among the lowest and there is a large gap in hours worked between women and men.

School schedules are not promotive of maternal employment either. The dates and timetables of public school in Switzerland are set by each of the 26 cantons independently ${ }^{4}$. Nevertheless, most schools have core times from around 8.30 a.m. until 11.30 a.m. and then from 1.30 p.m. until 3 p.m.. Outside of these core hours, there is generally no responsibility for the schools to offer any supervision. Usually, there is no school on one or two afternoons per week. Private or public childcare facilities increasingly cover these hours. The cantons and municipalities share the responsibility for the authorization, regulation, and supervision of formal childcare facilities. The allocation of the different tasks among the two government levels varies from canton to canton. However, the cantons generally have more authority.

If a school provides lunchtime and after-school care, this generally means that, for a fee, children can stay at school before school, during the lunch break, and in the afternoon. The school serves breakfast, lunch, and a small snack in the afternoon and there are a distinct number of caretakers, usually one caretaker per ten children, certified by the cantonal school authority. Facilities must also be such that there is sufficient room for pupils to do their homework, rest, and play.

In 2010, the cantons of Bern and Zurich introduced a new regulation obliging municipalities to assess the

\footnotetext{
${ }^{3}$ See e.g. (Girsberger et al. 2019) for figures on earnings trajectories of women in Switzerland around the birth of the first child.

${ }^{4}$ Compulsory schooling (classes 1 to 9 ) and pre-school education (1 to 2 years, approximately ages 4 to 6 ) are authority of the cantons and municipalities.

Cantons can also set curricula independently. There has been more and more

coordination between cantons recently and since 2011, there have been

national educational objectives which cantons are required to achieve.

Compulsory schooling and pre-school education are financed by the

municipalities and cantons through municipal and cantonal taxes.
}

demand for childcare needs of school children's parents regularly. If ten or more children are signed up for any time $\operatorname{slot}^{5}$, the municipality must provide this service. I exploit this change in regulation for the empirical analysis. The cantons of Basel City, Graubuenden, Lucerne, Neuchâtel, and Schaffhausen have since introduced similar regulations. All other cantons did not have any similar regulation as of 2016.

A federal impulse program implemented to create more childcare places helped municipalities cope with the large initial costs of the regulation. The program was introduced in 2003 with the goal of expanding childcare facilities, which would in turn help parents reconcile work and family life. Subsidies are awarded to new facilities or to facilities expanding their supply substantially. The funding covers initial fixed costs, which helps facilities cope with low initial capacity utilization. Financial assistance is awarded to both private and public facilities which fulfill quality requirements and which can show that there is demand for additional facilities. From its introduction until the year 2016, the program financed 1223 childcare facilities for school children ${ }^{6}$.

Costs of childcare are borne by parents with some municipalities or cantons granting subsidies either to childcare facilities directly or to parents. In both, Bern and Zurich, parental costs depend on parents' income. In Bern, municipalities are refunded by the canton for total labor costs minus parental contributions. Costs after redistribution and parental contributions are borne by the municipalities. Ceteris paribus, an increase in taxes in the cantons introducing new childcare facilities is expected.

In Switzerland, income taxes are raised by the municipalities, the cantons, and the federal government. Cantons are free to set the tax schedule, whereas municipality taxes correspond to a multiple of the cantonal taxes. Municipality taxes thus have no impact on the redistribution across incomes within a canton.

Approximately four times a year, Swiss citizens over the age of 18 have the right to vote. There are typically a number of bills which are voted upon on the same day. Voters receive an envelope containing the ballot as well as a small booklet with information on the topics voted upon approximately one month prior to the voting date. Voters can either choose to return the ballot in the anonymized envelope prior to the vote date or cast their vote directly in polling booths. Some cantons have introduced the option to vote electronically, an option which is also available for

\footnotetext{
${ }^{5}$ One slot refers to the time slot before school, at lunchtime, or in the afternoon. If a school offers care for all time slots, this would be three times a day, five times a week, i.e., there is a maximum of 15 slots per week.

${ }^{6}$ More information can be found on the homepage of the Federal Social Insurance Office. The law came into force on 1 February 2003 and has been extended multiple times until 2019, and till 31 December 2015, 300 million CHF was awarded. It is called "Federal Law on Financial Support for Childcare" ("Bundesgesetz über Finanzhilfen für familienergänzende Kinderbetreuung").
} 
Swiss citizens living abroad. The topics voted upon most frequently include healthcare, taxes, welfare, drug policy, public transport, immigration, asylum, and education (Cormon 2014).

There are three types of votes: initiatives, legislative referendums, and constitutional referendums. Initiatives allow Swiss citizens to propose constitutional amendments and new laws. For an initiative to come to a vote, a total of 100,000 valid signatures, which amounts to approximately $2 \%$ of the Swiss electorate, must be collected by the initiators. Referendums allow the electorate to challenge laws approved by the parliament. For these legislative referendums, 50,000 valid signatures must be collected by the opposition. In case of constitutional amendments proposed by the parliament, federal votes are mandatory and are called constitutional referendums. Constitutional referendums and initiatives proposing a constitutional change require that in addition to the majority of voters, a majority of cantons must approve ${ }^{7}$. All other referendums and initiatives only require a share of yes votes of $50 \%$ or higher in order to be passed. For a more detailed description of the Swiss system, see e.g. (Linder 2010).

\subsection{Measuring attitudes towards maternal employment} I propose vote outcomes of different national ballots on family policy as a measure for individuals' attitudes towards maternal employment. Vote outcomes as a measure of attitudes have been used, e.g., by Stutzer and Lalive (2004) or Slotwinski and Stutzer (2019). I exploit four ballots on family policy taking place in Switzerland from 1999 to 2013. The first two ballots are related to maternity leave, the third ballot is on the expansion of childcare, while the fourth ballot is concerning tax deductions for families.

Maternity leave policies have long been part of the political discourse in Switzerland. In 1945, a maternity protection period of 8 weeks after the birth of a child was introduced. During this time, mothers were not allowed to work and their employment contract could not be terminated. After that, there were several attempts to introduce paid maternity leave. The first ballot considered in this study took place in 1999 and was the fourth attempt to introduce paid maternity leave. The bill proposed 14 weeks of paid maternity leave for all mothers, paid through the value added tax, and was rejected by $61 \%$ of voters. The 2004 bill proposed 14 weeks of paid maternity leave with an income replacement of $80 \%$ only for mothers who were employed prior to giving birth, paid for

\footnotetext{
${ }^{7}$ More accurately, 20 out of the 26 cantons have one vote each, the other 6 , the so-called half cantons, have half a vote each (the half cantons are Basel-City, Basel-Country, Nidwalden, Obwalden, Appenzell-Innerrhoden, and Appenzell-Ausserrhoden). A majority of 12 votes is therefore sufficient to reach the cantonal majority. A canton's vote is determined by the popular vote of the canton's population. If a majority of the canton's population votes in favor, the whole cantonal vote is regarded as in favor of the proposed bill.
}

through employers' and employees' social insurance contributions, and was approved by $56 \%$ of voters. The next national ballot on family policy took place in 2013. The bill proposed a constitutional change where cantons and municipalities are obligated to regularly assess demand for childcare institutions and provide an adequate supply of such. If cantons were not to fulfill this requirement, the federal government could intervene. This would imply a reform compared to the status quo, with the whole responsibility lying at the cantonal level. The bill was supported by a majority of voters (54\%) but only 11 of the 26 cantons had a majority and hence, this constitutional change was not implemented. The last bill I consider is an initiative voted upon in November 2013. Families can deduct part of the costs of formal childcare from their taxable income. The initiative proposed the same deduction to be attributed to families where one parent stays home to take care of the children. Forty-two percent of the population voted in favor of this amendment. Figure 1 shows the results of the four votes at the municipality level ${ }^{8}$.

Figure 1 shows that approval rates are generally highest in the French speaking part of Switzerland (i.e., the cantons in the west) and in the Ticino, the southernmost and only exclusively Italian speaking canton of Switzerland. Support for the welfare state is generally higher in the French speaking part of Switzerland and provision of childcare has also traditionally been much higher in the French speaking part than in the German speaking part ${ }^{9}$. The same is true for the Ticino: The school system has long been such that it allows for the accommodation of work and family responsibilities.

In the empirical analysis, I use vote outcomes as a proxy for voters' revealed attitudes towards maternal employment. I argue that individuals who support maternal employment will in general be more likely to vote in favor of any institutions facilitating the compatibility of employment and family responsibilities and vote against promotion of the traditional family model ${ }^{10}$. Furthermore, it seems reasonable to assume that in the first three ballots, individuals who are in favor of maternal employment will vote yes. However, when it comes to the 2013 bill, I

\footnotetext{
${ }^{8}$ Data on approval rates are publicly available from the Swiss Federal Statistical Office and for all federal ballots since 1981 (https://www.bfs.admin.ch/bfs/de/ home/statistiken/politik/abstimmungen.html). Detailed information on all ballots is available from the Swiss Federal Chancellery (https://www.bk.admin. $\mathrm{ch} / \mathrm{bk} / \mathrm{de} / \mathrm{home} /$ dokumentation/abstimmungsbuechlein.html). The information is available in German, French, and Italian.

${ }^{9}$ Steinhauer (2018) exploits the border between the German and French speaking parts of Switzerland to examine how attitudes towards working mothers are related to employment and fertility decisions of women. He finds that German-born women are 15 to $25 \%$ less likely to work as mothers, and 20 to $25 \%$ more likely to remain childless by the age of 50 compared to women born in the French speaking part, a difference which is attributed to the difference in attitudes towards working mothers.

${ }^{10}$ Table 7 in Appendix A.2 shows that based on individual level data, individuals' party affinity, which proxies their attitudes, is a strong predictor of whether they vote yes or no and the predictive power is similar across the four ballots.
} 


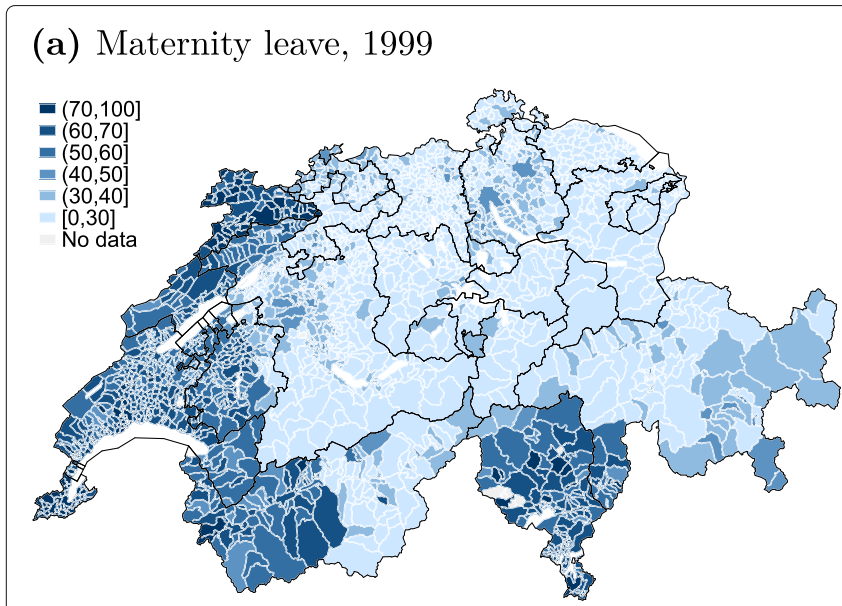

(b) Maternity leave, 2004

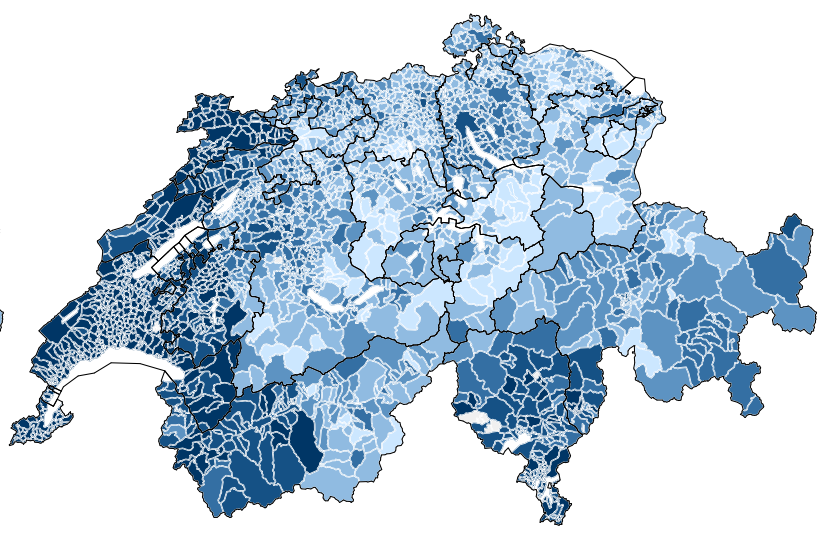

(c) Family policy, 2013

(d) Family initiative, 2013
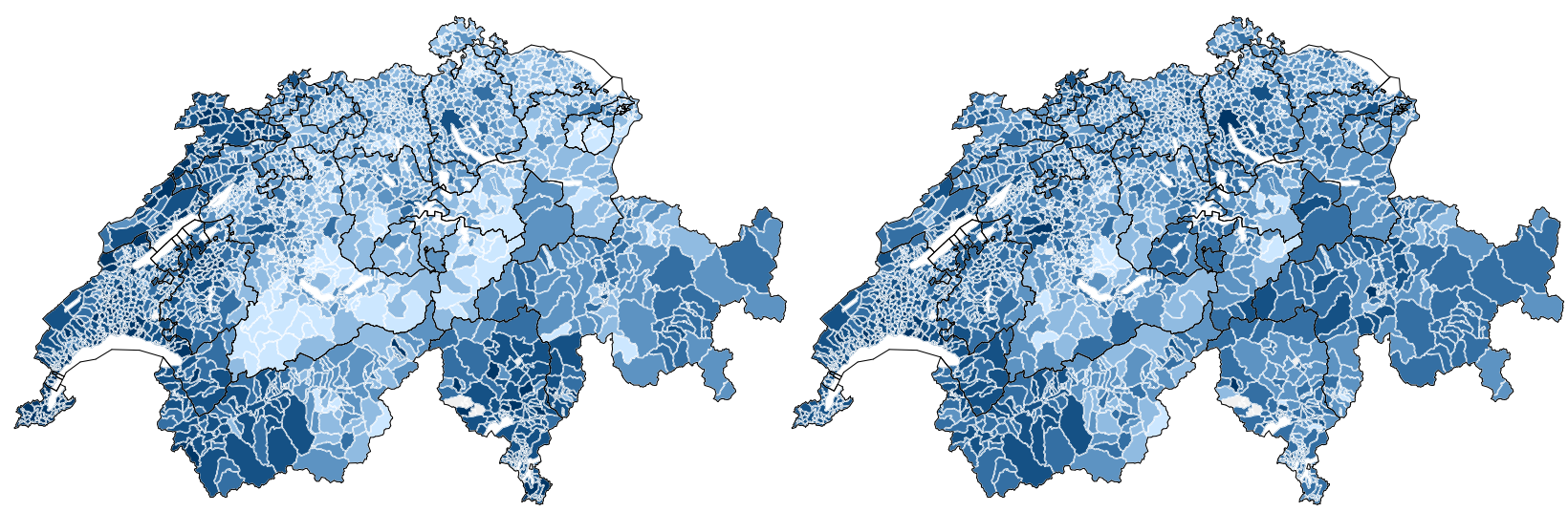

Fig. 1 The graphs show average approval rates for each municipality in Switzerland and for the four bills on policies promoting maternal employment considered in this analysis. White lines mark municipality borders; black lines mark cantonal borders. Light blue areas indicate low approval rates and dark blue areas indicate high approval rates

argue that voters supporting the traditional family model will vote yes. In order to compare the results of the four ballots, going forward I will consider the share of no votes for this last ballot.

The campaigns leading up to the ballots underline the similarities of the four ballots. The Swiss People Party, a well-funded populist party and the most prominent when it comes to policy campaigns in the last two decades, has been fighting bills promoting maternal employment, suggesting the introduction of the proposed institutions would lead to unhappy "state children." Examples of campaign posters can be found in Appendix A.1.

Post vote survey data also offer support that the vote results are a good measure of voters' attitudes towards working mothers, with a positive correlation between voters' attitudes towards maternal employment and the probability that they support a policy promoting the compatibility of work and family responsibilities ${ }^{11}$. As shown in Table 6 in Appendix A.2, this correlation is robust to the inclusion of additional covariates describing individual characteristics and, with a probability of voting yes which is 17 to 19 percentage points higher for voters supporting maternal employment, quite sizable. There is a positive albeit insignificant correlation for the fourth, the family initiative ballot, which may reflect that here, voting for the status quo implied preferences for maternal employment instead of the other way around.

\footnotetext{
${ }^{11}$ The question asked in the survey is whether the voter wants a country which actively promotes women's equality or a country where neither women nor men receive preferential treatment. The effect must therefore be seen as a lower bound for the correlation of the support for maternal employment and the probability to support a policy targeting this. There are probably many voters who do not want favorable treatment of women but who still think that policies that allow parents to conciliate work and family responsibilities more easily are important.
} 
In addition to measuring revealed instead of stated preferences, using vote outcomes has the advantage that the whole voting population is considered. In most surveys, only the population directly exposed to certain institutions is asked about their attitudes towards related topics. For instance, for the question posed in this paper, it is mostly parents or close relatives of the directly affected population that are asked about their attitudes towards childcare (see, e.g., Bauernschuster and Rainer 2012; Kotsadam and Finseraas 2011; Unterhofer and Wrohlich 2017). However, one's own preferences are to a large extent driven by social norms, which can only be measured when the whole population is considered. Observing all voters allows me to investigate a policy feedback effect on the whole population and thus consider the total effect institutions have on individuals' attitudes.

On the other hand, there are risks to using vote outcomes as a measure of attitudes. However precise the bill may be, there are always multiple policy areas that may be affected by its implementation. Therefore, there are multiple different reasons why any individual may vote in favor of or against a certain bill, which range from personal affectedness to a tradeoff between multiple public goods one might not directly benefit from. Section 6.2 addresses this concern in more detail.

As discussed, there are typically a number of bills voted upon simultaneously. Polling in Switzerland is usually 45 to $55 \%$, and individuals who vote on one bill on any specific day are more likely to also vote on the other bills. Voter composition is therefore affected by the entirety of bills voted upon on any specific date, which in turn may influence vote outcomes. Due to the differences-indifferences setting, this is only a concern if voter composition is affected differentially in the treatment and the control group. While I cannot present conclusive proof that this is not the case, Section 6.3 discusses why voter composition is unlikely to bias the results in the present setting.

\section{Identification}

\subsection{Hypotheses}

The division of work and family responsibilities within a couple are to a large extent driven by gender norms and gender roles. These gender norms are shaped by parents and peers, by social influences outside the family, and by the institutional environment (see, e.g., Bussey and Bandura 1999; Bowles 1998; Cislaghi and Heise 2020). This paper focuses on the effect of institutions on gender norms. I hypothesize that the introduction of lunchtime and after-school care affects individuals' gender attitudes, which is reflected in a change in vote outcomes.

In a setting with many small municipalities and where, in many cases, it is not economically necessary for both parents to have paid work, I argue that gender attitudes concerning working mothers are especially salient. I therefore expect municipalities in cantons with regulation concerning lunchtime and after-school care to experience the following adjustments: First of all, individuals living in municipalities introducing lunchtime and after-school care as a consequence of the new regulation experience an exogenous shock from the introduction of lunchtime and after-school care. This change could be through direct exposure, where parents benefit directly from lunchtime and after-school care for their children and see the benefits of the policies more clearly through the exposure, making it more likely for them to vote in favor of such policies in the future ${ }^{12}$. Additionally, family, friends, and neighbors will experience second hand how family life changes through the presence of these institutions. Also, the presence of the institutions themselves implies that it is socially acceptable for mothers to work, making it less pricy to express personal preferences in favor of working mothers, which increases the likelihood to vote in favor of policies promoting maternal employment. Section 6.2 expands on this point empirically ${ }^{13}$.

Secondly, the whole population in a canton with regulation concerning lunchtime and after-school care experiences a tax increase. Even though expenditures for lunchtime and after-school care constitute only a small part of total cantonal expenditures and the exact reasons for tax increases are usually not given, I nevertheless expect a negative effect on attitudes towards additional policies encouraging maternal employment through the (perceived) tax increase and its effect on the budget constraint. Since most of the public costs are incurred at the cantonal level, this negative effect is experienced by all municipalities in a canton with regulation, no matter whether they actually introduce lunchtime and afterschool care or not. I analyze empirically whether the positive effect in the municipalities actually introducing school care outweighs the negative tax effect. In addition, there may be an increase in maternal labor supply, which might in turn create additional tax revenue. I abstract

\footnotetext{
${ }^{12}$ The exposure to the policy must change the evaluation of the benefits by parents to change their approval rate differentially compared to the control group. If parents are fully aware of the benefits prior to exposure to the treatment, there is no reason why exposure should change attitudes of the directly affected group.

${ }^{13}$ There might be an "optimal level" of policies promoting maternal employment after which additional expansion is deemed unnecessary, making it less likely for affected individuals to vote for additional policies. However, I do not think that it is an issue in the current setting. First, Switzerland has seen a continued expansion in childcare facilities after the period considered in this paper, with treated cantons introducing 669 and control cantons introducing 684 new childcare institutions between 2013 and 2017, according to data from the federal impulse program covering initial costs of childcare facilities in case of sufficient demand. Also, in 2018, the program covering initial costs of childcare facilities was expanded by an additional four years due enduring demand. Second, the policy concerning childcare considered for the post-treatment period clearly stated that there was only to be continued expansion in case of sufficient demand. If municipalities had already reached the "optimal level," they would not have to react.
} 


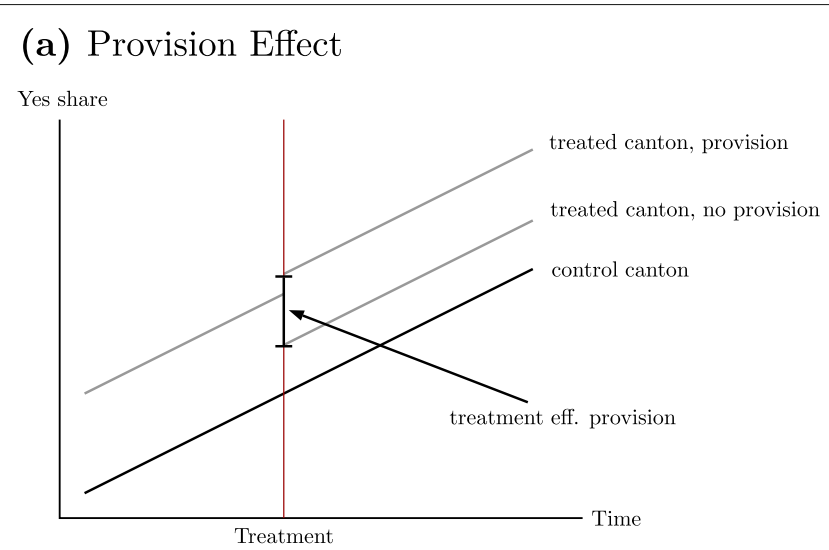

(b) Regulation Effect

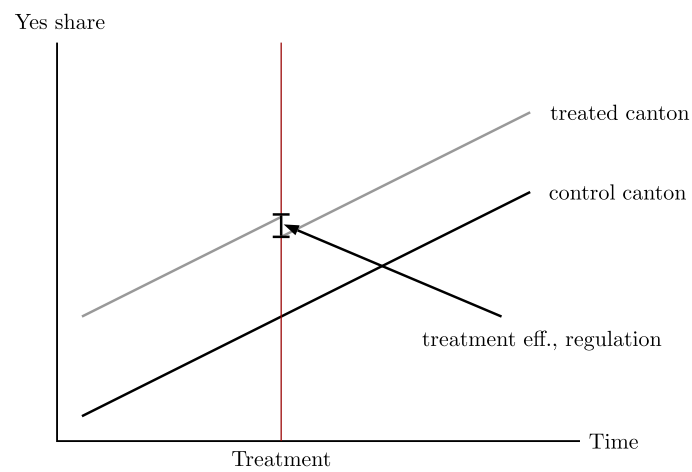

Fig. 2 This graph exemplifies the opposing provision and regulation effects. The provision effect displays the exemplified change in approval rates in the cantons with regulation, distinguishing between municipalities for which the new regulation becomes binding (due to demand for lunchtime and after-school care surpassing the 10 kids threshold) and municipalities for which the new regulation does not become binding. The regulation effect shows the hypothesized jump in approval rates on family policy related topics in cantons introducing a new regulation promoting lunchtime and after-school care compared to cantons without a change in regulation, without controlling for actual provision

from this effect for simplicity. Graphically, the two effects discussed above are shown in Fig. 2.

Figure $2 \mathrm{a}$ exemplifies the change in support of policies towards the promotion of maternal employment in municipalities with provision compared to municipalities with no provision of lunchtime and after-school care within cantons with regulation (treated cantons). Support of policies facilitating maternal employment has generally been increasing over the last decades. The line treated canton, provisions shows the change in support in the municipalities which introduce lunchtime and afterschool care after the new regulation is introduced. This change in support consists of both a positive effect from the public good expansion, as well as a negative effect from the tax increase. Municipalities in the treated canton but with demand below the threshold are not obligated to introduce lunchtime or after-school care and only experience the negative tax effect. The difference between the two lines displays the aggregate effect on voters' attitudes, controlling for the costs of the institutions as these are borne by all municipalities.

Figure $2 \mathrm{~b}$ compares the aggregate effect of the introduction of the regulation concerning lunchtime and afterschool care to the aggregate change in vote outcomes in the untreated cantons. Again, support of policies promoting maternal employment has generally increased over time. The control cantons experience no treatment and therefore no shock in the periods after the new regulation is introduced in the neighboring cantons. In the treated cantons, municipalities with introduction and after-school care experience both a positive effect on attitudes, as well as a negative cost effect. Municipalities with no provision but which are located in a canton with regulation only experience the negative cost effect. Controlling for the positive effects on attitudes, the regulation effect thus shows the effect of the regulation experienced by all municipalities in cantons with regulation.

\subsection{Empirical strategy}

In order to identify the causal effect of the availability of school care provisions on voters' attitudes towards maternal employment, a setting with exogenous variation in childcare supply is needed. Such a setting is rare since the provision of lunchtime or after-school care is likely influenced by population preferences. I address this inherent endogeneity problem by exploiting the introduction of a new regulation in the cantons of Bern and Zurich, where all municipalities are now required by law to provide lunchtime and after-school care in case of sufficient demand by the schools' children. I use municipalities in the neighboring cantons of Bern and Zurich as a control group. For the canton of Bern, these are the cantons of Aargau, Lucerne, Obwalden, and Nidwalden. The cantons to the West and South are excluded from the analysis since these are cantons with a French speaking majority, which have displayed very different trends with regards to childcare. I also exclude the canton of Solothurn from the analysis as they introduce the same regulation as Bern and Zurich but data on the actual provision of lunchtime and after-school care is not available. The canton of Zurich shares a border with the cantons of Aargau, Zug, Schwyz, Thurgau, St. Gallen, and Schaffhausen. Furthermore, all municipalities with lunchtime and after-school care prior to the introduction of the new regulation are excluded from the analysis. These municipalities clearly have different preferences and characteristics than the rest (e.g., larger population, more support for left wing parties, higher taxes) and show different trends from the rest. 
This is partly captured in data analyses of Swiss national votes of the past three decades, which show that increasingly, there have been diverging preferences between cities and the countryside (Koseki 2017). The small scale of Switzerland makes it equally likely that an individual in the control canton and in a treated canton works in the city (see, e.g., Felfe et al. 2016), which alleviates the concern that preferences of individuals commuting to the cities are affected differentially in the treatment and control region.

The regulation concerning lunchtime and after-school care creates two distinct groups of municipalities within a canton: those that are required to introduce lunchtime and after-school care after assessing demand and those that are not. If ten or more kids are signed up for any time slot, municipalities are required to provide these services. For a municipality to be obligated to introduce lunchtime and after-school care, it only requires a small fraction of parents in favor of such. Whether a municipality introduces school care does therefore not necessarily reflect the preferences of the majority of the population of a municipality. From the view of any single person, it is arbitrary, at least in the short term, whether they live in a municipality where lunchtime and after-school care are introduced.

The effects of the regulation and the provision are estimated applying a differences-in-differences (DiD) approach with two treatment margins: The provision effect measures the effect of actually introducing childcare facilities. The regulation effect shows the differential effect on vote outcomes from the introduction of the new regulation. The two treatment margins are estimated with the following equation:

$$
\begin{aligned}
\text { yes }_{m t}= & \alpha+\gamma_{1}\left(\text { provision }_{m t} \times \text { regulation }_{c} \times \text { post }_{t}\right) \\
& +\gamma_{2}\left(\text { regulation }_{c t} \times \text { post }_{t}\right) \\
& +\rho_{m}+\delta_{t}+\beta X_{m t}+u_{m t}
\end{aligned}
$$

$Y s_{m t}$ refers to the share of voters approving of a bill voted upon at time $t$ in municipality $m$. Provision $m t$ indicates whether a municipality $m$ has lunchtime and after-

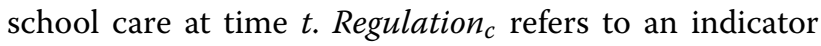
variable whether a municipality is either in the canton of Bern or Zurich and post t takes value 1 for the two ballots in the post period and 0 for the two ballots which took place prior to the introduction of the new regulation. The municipality specific coefficient $\gamma_{1}$ shows the effect of introducing lunchtime and after-school care on vote outcomes. The canton specific coefficient $\gamma_{2}$ estimates the treatment effect of the introduction of the regulation on lunchtime and after-school care, i.e., the differential change in support of policies encouraging the compatibility of work and family responsibilities between cantons with and without regulation concerning lunchtime and after-school care, controlling for the effect of the actual provision. A vector of municipality fixed effects $\left(\rho_{m}\right)$ and ballot fixed effects, estimated through $\delta_{t}$, and are included. $X_{m t}$ is a vector of municipality characteristics and $u_{m t}$ indicates the error term. Henceforth, I will refer to the effect on $\left(\right.$ provision $_{m t} \times$ regulation $_{c t} \times$ post $\left._{t}\right)$ as the provision effect and to the effect on regulation ${ }_{c t} \times$ post $_{t}$ as the regulation effect for simplicity.

\subsection{Identifying assumptions}

The empirical strategy identifies two possible effects: a so-called regulation effect capturing the change in voters' support induced by higher perceived costs and a provision effect, which captures the change in voters' support brought about by the actual provision of lunchtime and after-school care. Applying the strategy described above, the regulation effect is identified by comparing municipalities in cantons with regulation but without provision to municipalities in cantons without regulation. The provision effect is identified by a within canton comparison in cantons with regulation. I compare municipalities which are obligated to introduce lunchtime and after-school care to municipalities which are not obligated to introduce lunchtime and after-school care.

The identification of both effects relies on the common trends assumption. It requires that voting behavior between the groups of municipalities being compared evolves in parallel. For the identification of the regulation effect, this implies that in the absence of the regulation, vote outcomes in municipalities in cantons with regulation would have evolved in parallel to vote outcomes in municipalities in cantons without regulation. The causal identification of the provision effect requires that in the absence of the regulation and the actual provision, vote outcomes in municipalities introducing lunchtime and after-school care as a consequence of the regulation would have evolved in parallel to vote outcomes in municipalities in the same cantons but which were not required to introduce lunchtime and after-school care. The assumption that the regulation effect is the same in all treated municipalities is quite strong. It requires that the perceived tax effect is the same in municipalities with and without provision, which requires that individuals have the same reaction to a perceived tax increase whether they directly observe actual provision in their municipality or not. Column (1) in Appendix Table 10 shows that the tax multiplier does not change differentially in municipalities with provision compared to municipalities with no provision from the pre- to the post-treatment period. This is encouraging as it means that at least the actual tax change is constant across municipalities treated by the regulation.

Another issue might be reversed causality. If residents in a municipality are more in favor of maternal employment, they are also more likely to introduce lunchtime and after-school care. All municipalities with lunchtime and 
after-school care before the new regulation was introduced are not considered in this analysis. For those municipalities, I cannot credibly argue that they are on the same paths regarding their preferences. In municipalities that did not have lunchtime and after-school care prior to the new regulation, there were clearly no strong preferences regarding such institutions; otherwise, they would have introduced them endogenously. Differing attitudes that are time constant are taken care of with the municipality fixed effects. Attitudes are strikingly persistent in the absence of institutional changes (see, e.g., Alesina et al. 2013; Giuliano 2017; Teso 2019). I thus argue that similar trends in attitudes in the pre-treatment period are indication enough that they would have continued to evolve in parallel in the absence of the reform.

\section{Data and descriptives}

Data on vote outcomes and municipality characteristics are freely available on the website of the Swiss Federal Statistical Office ${ }^{14}$. I merge this data with data on income tax rates, which was provided by Parchet (2014). Data on the provision of lunchtime and after-school care for the canton of Zurich used to be freely available on the website of the cantonal statistical office ${ }^{15}$. For the canton of Bern, the same data was kindly provided by the cantonal department of education (Erziehungsdepartement Bern). I additionally include data on facilities receiving financial assistance through the federal impulse program implemented to create more childcare places. These data are freely available on the webpage of the Federal Social Insurance Office ${ }^{16}$.

In Switzerland, there have been a lot of municipality mergers over the years. All data are aggregated and merged such that the data correspond to the municipalities existing in 2016. In 2016, there were 2240 municipalities. Together, the municipalities in the cantons included for the analysis had a population of 4.7 million in the year 2013. This corresponds to about $60 \%$ of the Swiss population. Excluding all municipalities with lunchtime or after-school care in 2004 leaves me with $32 \%$ of the total population of Switzerland or $56 \%$ of the population in the cantons considered.

Enforcement of lunchtime and after-school care in the cantons of Bern and Zurich is contingent on the number of parents who sign up their kids for these structures. Figures 3 and 4 indicate the presence of lunchtime and

\footnotetext{
14Vote outcomes: https://www.bfs.admin.ch/asset/de/px-x-1703030000_101 Election National Council: https://www.pxweb.bfs.admin.ch/pxweb/de/px-x1702020000_105 Population: https://www.pxweb.bfs.admin.ch/pxweb/de/px$\mathrm{x}$-0102020000_201

${ }^{15}$ The data was downloaded on 22 November 2016 from the website of the cantonal statistical office and for the years 2004 to 2013 . However, when I last checked, the data was no longer publicly available.

${ }^{16}$ https://www.bsv.admin.ch/bsv/de/home/finanzhilfen/kinderbetreuung. html. The data are only available on the German, French, or Italian version of the page, not on the English version.
}

after-school care for all municipalities in the cantons of Bern and Zurich in the school year 2003/2004, before the introduction of the new regulation, and for the school year $2012 / 2013$. Since data on the prevalence of lunchtime and after-school care in the year 2004 are only available for the canton of Zurich, I proxy the supply in 2004 using data from the federal impulse program. The data distinguish whether a facility is new or whether they receive financial aid to expand the current supply, and on the exact date they start receiving financial aid. I define all municipalities with a facility starting to receive financial aid for a new facility in 2006 or earlier as having lunchtime and after-school care prior to the introduction of the new regulation. Additionally, I define all municipalities with a facility expanding its supply in 2009 or earlier as having lunchtime and after-school care before the new regulation was introduced ${ }^{17}$.

Figure 3 shows the prevalence of lunchtime and afterschool care in the canton of Zurich before and after the introduction of the new regulation. One immediately notices a cluster of municipalities with after-school care in and around the city of Zurich and along the lake of Zurich ${ }^{18}$. All of these municipalities describe the metropolitan area of Zurich. In the canton of Zurich, the municipalities which adopted lunchtime and after-school care are mostly in the more rural areas further away from the metropolitan areas of Zurich and Winterthur.

The canton of Bern is larger in terms of the area it covers and has more rural municipalities. As in Zurich, the municipalities which have lunchtime and after-school care prior to the introduction of the new regulation are mostly in the metropolitan areas around the largest cities, Bern and Bienne, as shown in Fig. 4. Since the canton of Bern has more rural municipalities than the canton of Zurich, there are also more municipalities introducing lunchtime and after-school care in Bern.

The municipalities in the cantons considered can be assigned to one of four groups: The first group consists of municipalities which have lunchtime and after-school care prior to the introduction of the new regulation, which are excluded from the analysis. The remaining municipalities can be placed into three distinct groups: within the cantons with regulation, one group consists of all municipalities introducing lunchtime and after-school care as a consequence of the regulation, and another group consists of all municipalities where less than 10 children sign up for any slot and for which the new regulation is therefore not binding. The third group consists of the remaining municipalities, i.e., the municipalities in the control cantons,

\footnotetext{
${ }^{17}$ The results are stable to changing the cutoff to an earlier or later year for new and expanding facilities respectively.

${ }^{18}$ The city of Zurich is the largest municipality of the canton and can be found at the northern end of the lake of Zurich, the white narrow area entering the canton from the south.
} 
(a) School year 2003/2004

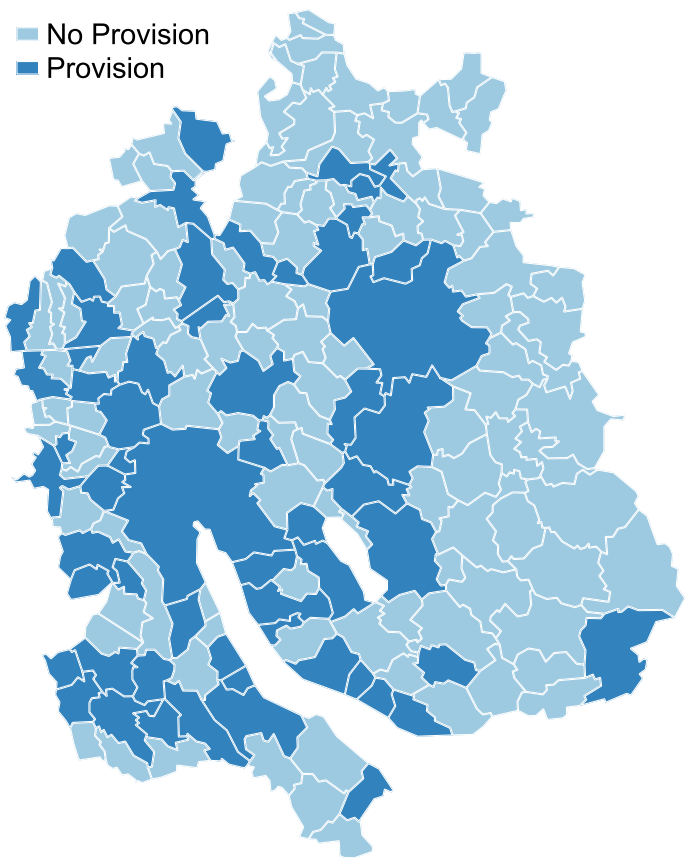

(b) School year 2012/2013

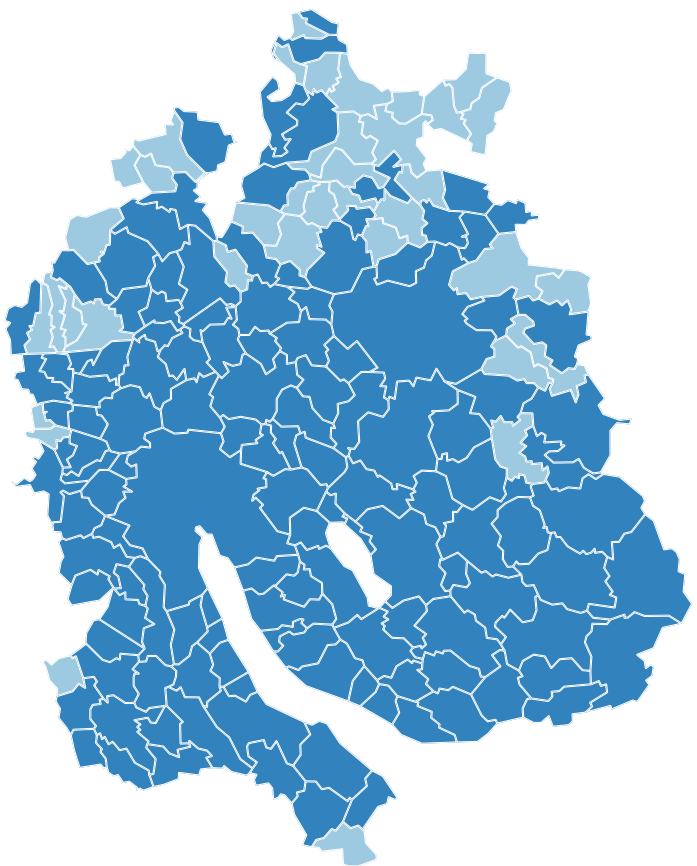

Fig. 3 Prevalence of lunchtime and after-school care in the canton of Zurich before and after the introduction of the new regulation. Light blue areas show municipalities which do not offer lunchtime or after-school care in the given period, whereas dark blue areas show municipalities with lunchtime and after-school care in the given period

(a) School year 2003/2004

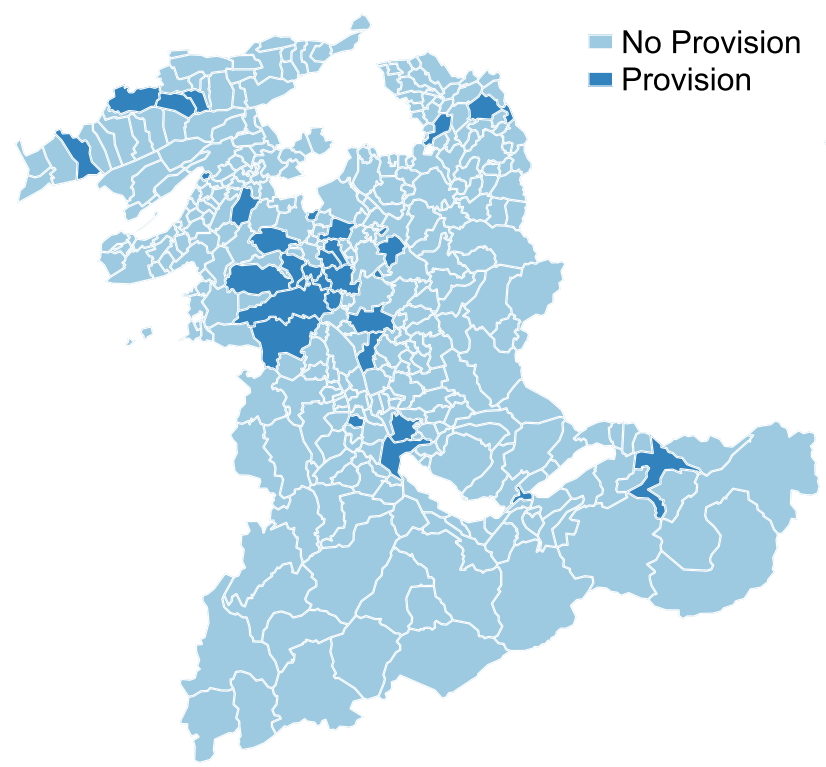

(b) School year 2012/2013

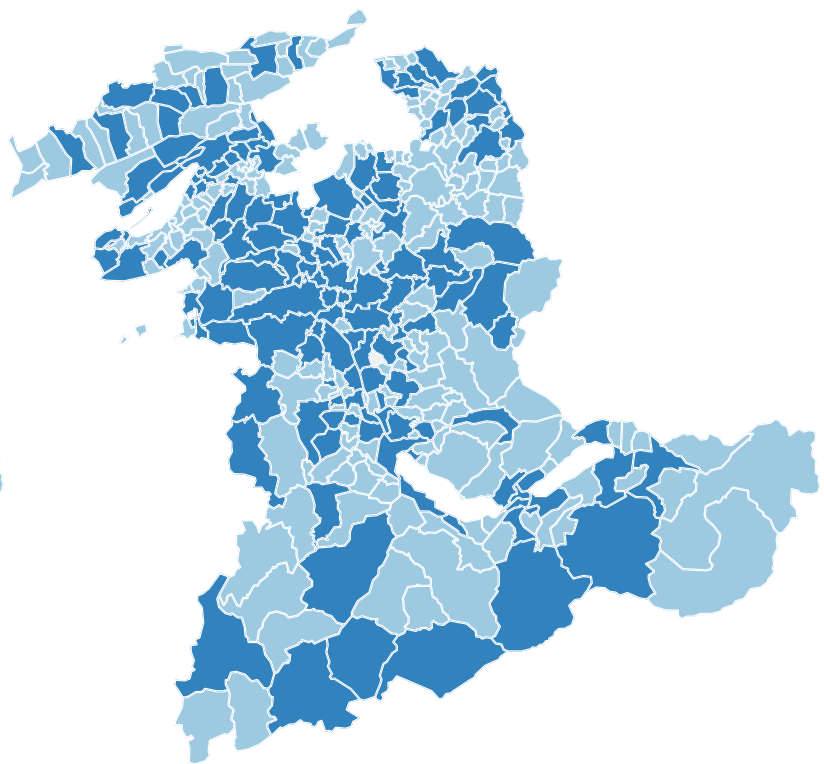

Fig. 4 Prevalence of lunchtime and after-school care in the canton of Bern before and after the introduction of the new regulation. Light blue areas show municipalities which do not offer lunchtime or after-school care in the given period, whereas dark blue areas show municipalities with lunchtime and after-school care in the given period 
where there is no change in regulation. Figure 5 shows the population weighted means in vote outcomes for these three groups and for the four federal ballots used in the analysis. Appendix Table 8 shows descriptive statistics for the three types of municipalities.

Before 2010, i.e., before the new regulation became binding in the cantons of Bern and Zurich, support for policies promoting maternal employment was on average lowest in the municipalities in the control group and highest in municipalities with regulation and provision. The pre-treatment differences cancel out in the DiD setting. After the treatment, a convergence in vote outcomes between cantons with and without regulation is observed: The average approval rate is now lowest in municipalities with regulation and no provision and still highest in municipalities with regulation and provision. This raw graph indicates that the introduction of the new regulation has, on average, a negative effect on support of policies encouraging maternal employment, suggesting that the negative effect from the increase in public expenditures outweighs the positive effect on voters' attitudes from the actual provision.

\section{Results}

The DiD estimates of Eq. (1) measure the effect of the introduction of lunchtime and after-school care at public schools $\left(\gamma_{1}\right)$ and the effect of only the regulation $\left(\gamma_{2}\right)$. Table 1 shows these measures for different specifications. All four specifications estimate Eq. (1) using OLS. The observation unit are municipalities and the dependent variable are vote outcomes of four ballots on family policy related topics, taking place between 1999 and 2013. To account for serial correlation, standard errors are clustered at the municipality level.

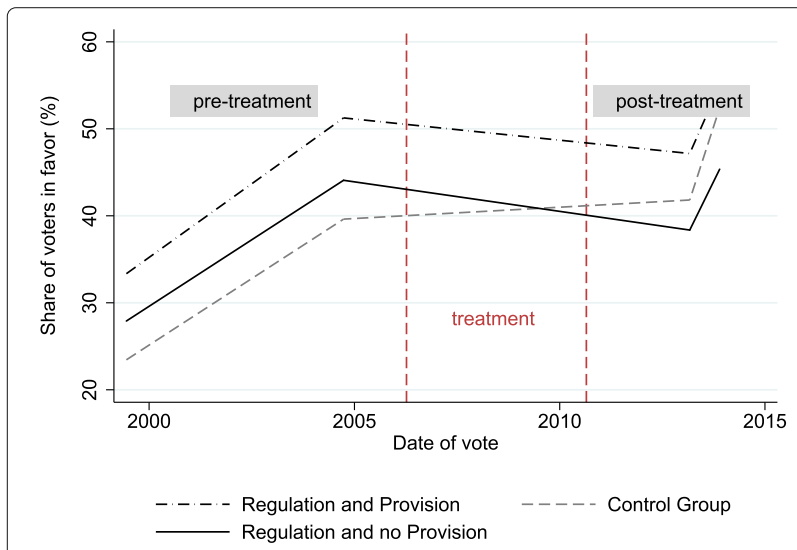

Fig. 5 Vote outcomes of bills promoting maternal employment in the municipalities with no regulation (mun. in the control cantons), municipalities with regulation but no provision, and municipalities with regulation and provision. The results displayed show population weighted means in vote outcomes for each of the three groups
Table 1 DiD estimates: effect of lunchtime and after-school care on vote outcomes

\begin{tabular}{lllll}
\hline & $\mathbf{( 1 )}$ & $\mathbf{( 2 )}$ & $\mathbf{( 3 )}$ & $\mathbf{( 4 )}$ \\
\hline Provision & $2.91^{* * *}$ & $2.50^{* * *}$ & $2.08^{* * *}$ & $1.80^{* * *}$ \\
& $(0.597)$ & $(0.702)$ & $(0.579)$ & $(0.600)$ \\
Regulation & $-9.71^{* * *}$ & $-8.72^{* * *}$ & $-7.66^{* * *}$ & \\
& $(0.503)$ & $(0.543)$ & $(0.930)$ & \\
Municipality FE & Yes & Yes & Yes & Yes \\
Ballot FE & Yes & Yes & Yes & Yes \\
Inc. tax & No & No & Yes & No \\
Canton x ballot FE & No & No & No & Yes \\
Number of mun. & 915 & 742 & 915 & 915 \\
Number of obs. & 3658 & 2966 & 3658 & 3658
\end{tabular}

This table presents the DiD estimates, $\hat{\gamma_{1}}$ and $\hat{\gamma_{2}}$, of Eq. (1). The regulation coefficient shows the differential change in vote outcomes of municipalities in cantons with regulation compared to municipalities in cantons without regulation regarding lunchtime and after-school care in public schools, controlling for the differences in provision within the treated cantons. The provision coefficient estimates the differential change in vote outcomes in municipalities which introduce lunchtime and after-school care as a consequence of the new regulation compared to those which do not. Inc. tax consists of the income tax (cantonal + municipality + church taxes) for singles, married couples with no children, and married couples with two children, each for yearly net incomes of CHF 80,000.-, 100,000.--, 150,000.-, and 200,000.-. In specification (4), canton $\times$ municipality FE are applied, and the regulation coefficient can no longer be identified due to collinearity. In all specifications, population weights are applied to account for the fact that municipalities differ in their population. The numbers in parentheses show the standard errors, clustered at the municipal level. ${ }^{*} p<0.10,{ }^{* *} p<0.05,{ }^{* * *} p<0.01$

The dependent variable in all four specifications is the approval rate on topic $t$ in municipality $m$. In specifications (1) , (3), and (4), the sample consists of all municipalities in the treated cantons Bern and Zurich, as well as the ten neighboring control cantons, except for municipalities which already had lunchtime or after-school care prior to the introduction of the new regulation. Municipality and time fixed effects are included in all specifications ${ }^{19}$. The variable provision takes value 1 for all municipalities which have lunchtime and after-school care after the regulation requiring them to do so in case of sufficient demand is introduced. It takes value 0 for all other municipalities and for the pre-treatment period. The variable regulation takes value 1 for all municipalities in the cantons with regulation (Bern and Zurich) in the post-treatment period and value 0 in the pre-treatment period and for all municipalities in the neighboring cantons.

The estimates in specification (1) show that as a consequence of the introduction of lunchtime and after-school care, support for policies promoting maternal employment increases by 2.91 percentage points compared to

\footnotetext{
19 The regulation variable is defined at the cantonal level, taking value one for the cantons with regulation of lunchtime and after-school care and zero otherwise. It can therefore not by identified in the presence of cantonal time trends, as applied in specification (4).
} 
municipalities with no provision. However, this positive effect is more than offset by a decrease in support of 9.71 percentage points compared to the control group.

Specification (2) shows the same effect for the subsample of municipalities where a majority of voters voted against the 2004 bill on maternity leave to make sure that the effect is not purely driven by municipalities which already have positive attitudes towards maternal employment prior to the introduction of the new regulation. The 2004 bill is used to make this distinction as this bill was approved at the ballots by a majority of voters (56\%). An approval rate below 50 percent therefore indicates approval below the Swiss average; these municipalities were outvoted by the rest of Switzerland. This restriction reduces the sample to 742 municipalities. Both the provision effect and the regulation effect become slightly smaller through this restriction and remain, however, highly significant.

In specification (3), tax rates for different income levels and family types are added. It is of course not feasible to control for all tax rates for all family types. The inclusion of these should decrease the regulation effect at least by some its real part, if it is driven by a tax increase. If the regulation effect is purely driven by the perception of a tax increase, this will not be captured by this inclusion. The regulation coefficient in specification (3) decreases by $21 \%$ compared to the regulation effect found in specification (1), which is based on the same sample of municipalities. While I cannot conclude that the regulation effect is purely driven by a real tax increase, this solidifies the hypothesis that the introduction of the new regulation leads to a reduction of approval rates due to a (perceived) tax increase.

Specification (4) includes canton $\times$ ballot fixed effects. In their presence, the regulation effect can no longer be identified due to collinearity. However, it allows me to control for cantonal changes over time which are homogeneous across municipalities, such as changes in the cantonal tax schedule. In Appendix Tables 9 and 10, I take a closer look at how such variables might change differentially between treated and control cantons, and within the treated cantons across municipalities with provision and without. I look at the municipality tax multiplier, voter turnout, the birth rate as a fraction of a municipality's population, as well as the immigration and emigration rates. These variable are not directly added to the estimation, since they might be bad controls. Especially voter turnout and immigration rates might be mechanisms rather than changes happening independently from the treatment. It is conceivable that changes in tax rates lead to migration across cantonal borders or that the introduction of lunchtime and after-school care attracts families with positive attitudes towards maternal employment to a municipality. It is further possible that voter turnout declines in municipalities with provision as there is no longer the same necessity for investments towards institutional childcare. Appendix Table 9 shows the results of regressing these variables on provision and regulation, including municipality fixed effects and ballot fixed effects. The results show that in municipalities with regulation, voter turnout and the emigration rate increase compared to the control cantons. The increase in the emigration rate is in line with the theory on tax mobility: if taxes increase, individuals are more likely to move away, e.g., to a neighboring canton. It is less clear why we would see a positive correlation between regulation and turnout. Considering regulation and provision jointly, there is a significant increase in voter turnout in municipalities with regulation and no provision compared to municipalities with no regulation, while municipalities with regulation and provision move in parallel to municipalities with no regulation. An explanation could be that individuals in municipalities with just regulation but no provision want to make sure that there were no additional subsidies for maternal employment, which is reflected in increased turnout ${ }^{20}$. Compared to that, municipalities with provision experience a benefit in addition to the costs, which leads to no change overall compared to the municipalities in cantons with no regulation.

Appendix Table 10 shows the same results as Table 9 but allowing for canton $\times$ ballot fixed effects. First, this allows me to additionally look at the tax multiplier as a dependent variable, as the canton $\times$ ballot fixed effects control for changes in the cantonal tax schedules. As detailed above, within the cantons with regulation, I do not expect the municipality tax multiplier of municipalities with provision to change differently to the tax multiplier of municipalities with no provision; the public costs of the new facilities are born by the cantons. This is confirmed in column (1) of Table 10. The tax multiplier does not change differentially in municipalities with provision compared to municipalities with no provision. Even after controlling for canton $\times$ ballot fixed effects, there is still the negative change in voter turnout as described above. There is also a slight reduction in birth rates of $0.5 \%$, which is significant at the $10 \%$ level. This change seems, however, arbitrary since, if anything, we would expect birth rates to increase if there are more childcare facilities. While immigration into municipalities is no longer significant and much smaller than in the specification without canton $\times$ ballot fixed effects, it is still sizable and

\footnotetext{
${ }^{20}$ Appendix Table 11 indeed shows that turnout and voter support are negatively correlated.
} 
pointing towards increased migration into municipalities with provision within cantons with regulation ${ }^{21}$.

The results suggest that the introduction of lunchtime and after-school care increases support of policies facilitating maternal employment by 1.8 to 2.9 percentage points. Section 6.2 shows that this effect is unlikely to be driven by parents only, but by the population as a whole. One concern might be that not only the population of municipalities with provision of lunchtime and afterschool care observe its benefits, but also individuals living in neighboring municipalities with no such provision. The policy would therefore create a spillover and increase approval rates in the control group, too. If this is the case, the effect found presents the lower bound of the total effect, which would consist of the positive spillovers to neighboring municipalities in addition to the effect found for municipalities with provision. The regulation itself seems to decrease support for policies facilitating maternal employment by 8.7 to $9.7 \%$, which can be explained by (perceived) public costs of these institutions, as shown in specification (3). This point will be analyzed in more detail in Section 6.1.

\section{Discussion}

\subsection{Public expenditures and vote outcomes}

Cantons in Switzerland are free in setting the cantonal tax schedule and deductions. It is therefore not feasible to consider the full tax schedule for all incomes and family types in the analysis above. The costs of lunchtime and after-school care are partly borne by the parents, partly by the cantons and municipalities. The municipal and cantonal costs are reflected in an increase in public expenditure, which would result in a tax increase ceteris paribus.

Figure 6 shows the relative change in income taxes in cantons with regulation compared to those without for different income levels. There is a separate tax schedule for married couples and for singles. Furthermore, married couples with children can make different tax deductions than those without children, including deductions of formal childcare costs. Figure 6 displays the results of running Eq. 2 separately for each level of income and for married, married with two kids, and single households. Tax $x_{m t}^{y}$ refers to the tax rate on income $y$ in municipality $m$ at time $t$.

\footnotetext{
${ }^{21}$ Appendix Table 11 shows the same estimations as Table 1 including all of these variables as covariates. If the provision and regulation effects are purely driven by changes in attitudes or perceived instead of real tax effects, they should still be present after the inclusion of these covariates. While they decrease in magnitude in absolute terms, both effects persist in the presence of these covariates in most specification. While still positive, the provision effect is no longer significant when canton $\times$ ballot fixed effects are included in addition to the covariates. I can therefore not reject the hypothesis that the provision effect is purely driven by real reactions to the introduction of lunchtime and after-school care.
}

$$
\begin{aligned}
\operatorname{tax}_{m t}^{y}= & \beta^{y}+\mu_{1}^{y}\left(\text { provision }_{m t}^{y} \times \text { regulation }_{c t}^{y} \times \text { post }_{t}\right) \\
& +\mu_{2}^{y}\left(\text { regulation }_{c t}^{y} \times \text { post }_{t}\right) \\
& +\rho_{m}^{y}+\delta_{t}^{y}+v_{m t}^{y}
\end{aligned}
$$

Each dot shows the coefficient estimate of $\mu_{2}$ of Eq. 2 and its confidence bound. The relative tax rates for married couples with no children and for singles remain fairly constant for low incomes and increase for incomes above median income. For married couples with two children, the relative tax rates only increase at the very top, which is incomes above CHF 200,000. Singles on average experience the largest tax increase and singles are also less likely to vote in support of policies promoting maternal employment in the post-treatment period (Appendix Table 7). However, the time window considered here is quite large and there might be other changes in cantonal and municipal tax rates that are uncorrelated to the expansion of public childcare. Furthermore, I do not have information on why and how tax rates were adjusted for each municipality.

In a next step, I will look at the canton of Bern separately. I have more detailed data on the costs of lunchtime and after-school care in Bern, which allows for a better understanding of the interaction of public expenditure and vote outcomes.

The total costs of lunchtime and after-school care in the canton of Bern in the year 2013 amount to about CHF 50.7 million, which corresponds to approximately $0.3 \%$ of total cantonal tax income or CHF 13.- per hour and child. About $24 \%$ of the costs are born by the parents directly. The remaining CHF 38.8 million correspond to $0.27 \%$ of total public expenditures or $0.68 \%$ of total income and wealth tax revenue of the canton of Bern for the year $2013^{22}$.

If the hypothesis that voter support decreases when taxes are increased holds, I expect that in the group of municipalities with provision of lunchtime and afterschool care, the positive effect of the provision on attitudes should decrease as per capita costs borne by the municipality increase.

Figure 7 shows the population weighted means in vote outcomes for municipalities in the canton of Bern and for each of the four ballots. It distinguishes between municipalities with provision of lunchtime and after-school care and per capita costs below the median, and municipalities with provision and costs above the median. Comparing the groups with higher and lower costs, there is no difference in the pre-treatment period. In the post-treatment period, support of family policy related topics increases in the group of municipalities with costs below the median compared to municipalities with costs above the median.

\footnotetext{
${ }^{22}$ Data on tax revenue can be downloaded from the website of the Swiss Federal Finance Administration: https://www.efv.admin.ch/efv/de/home/ themen/finanzstatistik/daten.html
} 
(a) Married, no children

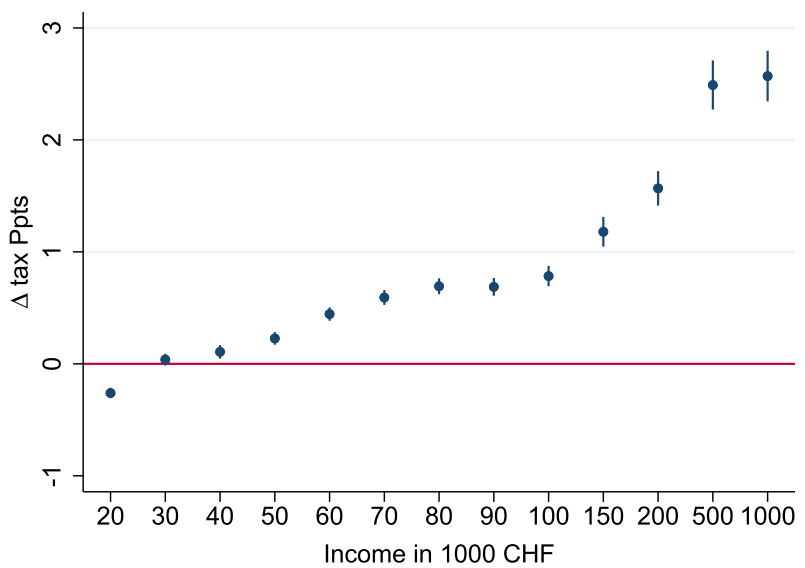

(b) Married, two children

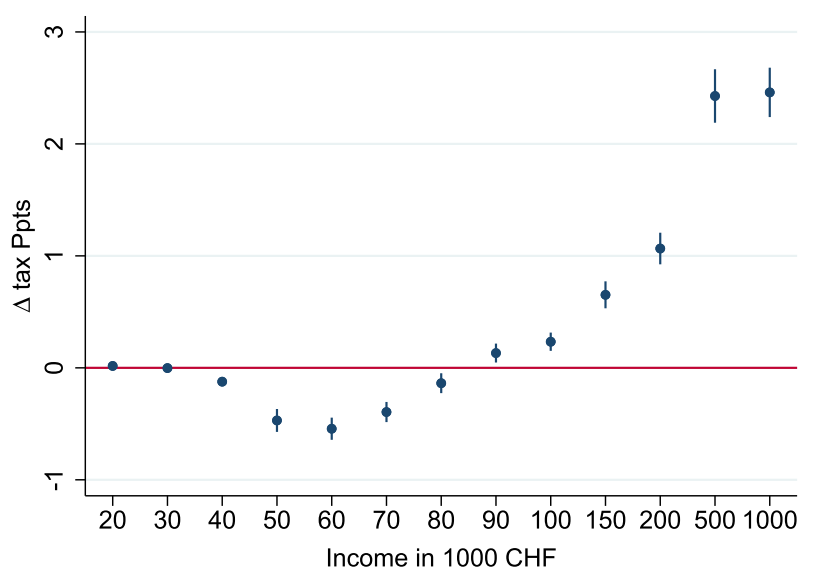

(c) Single

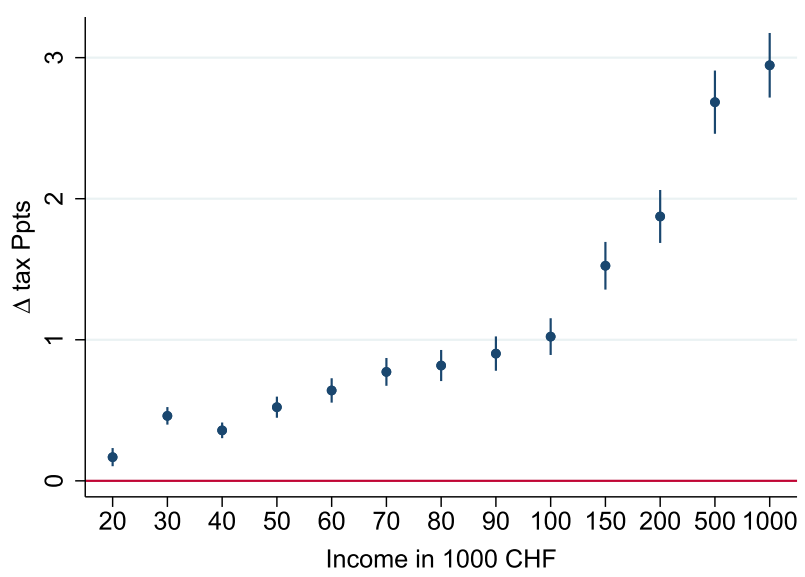

Fig. 6 Estimated differential change in cantonal income tax between the cantons with regulation and control cantons for different incomes (CHF 20,000 to CHF 1,000,000) and for different types of tax payers (married, married with two children, single). Each dot shows a coefficient estimate $\mu_{2}^{y}$ of Eq. 2 and its 95\% confidence interval, i.e., the differential change in income taxes for an individual with income $y$ given they are married, married with two children, or single. The corresponding estimates are displayed in Appendix Table 12

Table 2 introduces costs into the model specified in Eq. (1). Since information on costs is only available for the canton of Bern, only municipalities in this cantons are considered for this analysis and for the treated group. The first specification shows the baseline effect for the canton of Bern before the inclusion of costs. The estimate on provision is still positive and no different from the effect found in the estimation including the canton of Zurich (Table 1, specification (4)). In specification (2), provision is interacted with a dummy variable indicating costs above median costs for municipalities with provision of lunchtime and after-school care ${ }^{23}$. The estimate now

\footnotetext{
${ }^{23}$ The p.c. costs per municipality and year and after redistribution range from CHF -17.- to CHF 37.-, with a mean of CHF 6.53.- and median of CHF 4.07.More descriptive statistics for municipalities in the canton of Bern are displayed in Table 13.
}

indicates that for the group of municipalities with provision of lunchtime and after-school care and with costs below the median, there is a significant positive effect of the provision on vote outcomes. The effect for municipalities with costs above median costs is not significantly different. An additional test shows that the total provision effect for the group with high costs is not significantly different from zero $\left(H_{0}: \theta_{\text {provision }}+\theta_{D \text {.costs }>p 50 \times \text { prov. }}=0\right)$. Specification (3) introduces a continuous variable of per capita costs. It confirms that there is a positive effect of provision on approval rates, which is decreasing in per capita costs. Specification (4) additionally includes the covariates discussed in detail above. As discussed, these covariates might be bad controls. However, now that I am able to control for per capita costs born by the public, 


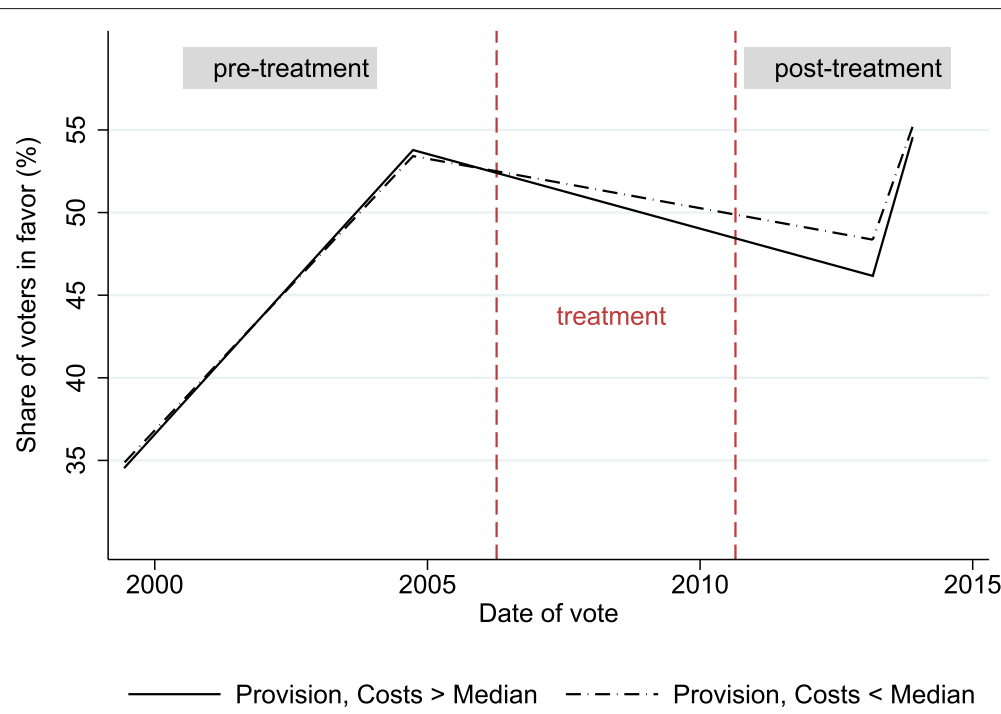

Fig. 7 Vote outcomes of bills promoting maternal employment for the canton of Bern in municipalities with regulation but no provision and municipalities with regulation and provision. The results displayed show population weighted means in vote outcomes for the two groups

there is still a significant and positive effect of provision on support for policies promoting maternal employment, which corroborates the hypothesis that the introduction of lunchtime and after-school care has a direct effect on voter's attitudes.

Table 2 DiD estimates for municipalities in the canton of Bern and control cantons, including per capita costs of institutions borne by the public

\begin{tabular}{lllll}
\hline & $\mathbf{( 1 )}$ & $\mathbf{( 2 )}$ & $\mathbf{( 3 )}$ & $\mathbf{( 4 )}$ \\
\hline Provision & $1.77^{* *}$ & $2.39^{* * *}$ & $2.68^{* * *}$ & $1.40^{* *}$ \\
& $(0.729)$ & $(0.751)$ & $(0.694)$ & $(0.632)$ \\
D.cost> p50 $\times$ prov. & & -1.46 & &
\end{tabular}

\section{(1.053)}

Cost $\times$ prov

$-0.13^{* *}-0.11^{* *}$

Municipality FE Yes

Canton $x$ ballot FE

Covariates

Number of mun.

Number of obs 3214

This table presents the DiD estimate of the provision effect for municipalities in the canton of Bern only. The provision coefficient estimates the differential change in vote outcomes in municipalities introducing lunchtime and after-school care as a consequence of the new regulation compared to those that do not. All four specifications include canton $\times$ ballot fixed effects. Specification (2) includes an interaction term of provision and a dummy variable indicating per capita costs of lunchtime and after-school care that surpass median costs. Specifications (3) and (4) include an interaction term of provision and a continuous per capita costs variable. All specifications include municipality fixed effects. Covariates include voter turnout, municipality tax multiplier, immigration rate, emigration rate, and birth rate. In all specifications, population weights are applied to account for the fact that municipalities differ in their size. The numbers in parentheses show the standard errors, clustered at the municipality level. ${ }^{*} p<0.10,{ }^{* *} p<0.05,{ }^{* * *} p<0.01$
A possible explanation for the differing costs is that not all municipalities receive subsidies from the federal impulse program. Municipalities receiving subsidies from the federal impulse program seem to have lower costs, on average, than municipalities which do not receive subsi$\operatorname{dies}^{24}$. Why some municipalities do not receive subsidies is unclear. In fact, since lunchtime and after-school care facilities are only opened in case of sufficient demand and since they already have to satisfy cantonal quality guidelines, they also fulfill the requirements to qualify for the impulse program. It is therefore unclear why some municipalities do not receive any subsidies.

The effect of costs on vote outcomes should therefore not be taken at face values. A more detailed analysis of why per capita costs after parental contributions and after wages differ is necessary. Also, a closer investigation of how voters become aware of costs is needed. Due to the data restrictions, the current setting does, unfortunately, not allow for a more detailed analysis of the mechanisms. Nevertheless, the costs of institutions in place seem to play an important role in voters' subsequent support of related policies.

\subsection{Are affected parents driving the positive effect on approval rates?}

The question remains whether the positive effect is driven solely by the affected population, i.e., by parents benefitting directly from policies facilitating maternal employment. Due to the DiD strategy, level differences

\footnotetext{
${ }^{24}$ Applying the same sample restrictions as above, there are 27 municipalities which receive subsidies and 88 municipalities which do not receive subsidies. Per capita costs are CHF 7.18.- in municipalities receiving subsidies and $\mathrm{CHF}$ 10.09.- in municipalities not receiving subsidies on average.
} 
are controlled for. In the extreme case, if all parents are generally in favor of policies promoting maternal employment, they would all approve of all four bills considered and would therefore not constitute the population driving the effect. Only if the treatment affects their preferences towards such policies, e.g., if through exposure they become aware of the benefits, could they be the drivers of the effect.

As approval rates are measured at the municipal level, it is not possible to directly identify the population driving the effect. The fraction of voters with school-aged children amounts to approximately $16 \%{ }^{25}$, which clearly surpasses the change in approval rates of $2.9 \%$. If the introduction of lunchtime and after-school care increases the fraction of parents approving of the bills in the posttreatment period compared to the pre-treatment period by $20 \%$, while it remains constant in the control group, the entire effect would be driven by parents of school-aged children.

I rely on post-vote surveys to shed more light on the question, whether the effect is purely driven by a change in approval rates by the directly affected population. I test whether parents in treated cantons vote differently from the rest of the population in the treated cantons in the post-treatment period, controlling for pre-treatment differences. Furthermore, I test whether attitudes towards gender equality of parents in treated cantons differ from the rest of the population in the treated cantons in the post-treatment period, controlling for pre-treatment differences. Since the data do not include municipality identifiers, I can only estimate the differential change in approval rates in cantons with regulation, compared to cantons with no regulation, i.e., the composited of the regulation and provision effect. The results of these regressions are shown in Table 3.

I find that the composite of the regulation and provision effect amounts to zero, based on this data (specification (1). Specification (2) includes an indicator for whether an individual has children living in the same household, as well as interaction terms with post and whether they live in a canton with regulation. It shows that parents are on average more likely to vote yes, with a larger effect for parents living in cantons with regulation (albeit, none of the effects are significant at any of the conventional level.

\footnotetext{
${ }^{25}$ This is calculated based on STATPOP data for the year 2013 for the municipalities included in the analysis ("Ständige und nichtständige Wohnbevölkerung nach institutionellen Gliederungen, Staatsangehörigkeit (Kategorie), Geschlecht und Alter"). The data shows the permanent population for each municipality by age. The fraction of affected parents is calculated by dividing the number of children aged 0 to 12 by the total population aged 18 or older, the population allowed to vote. It therefore assumes that families have on average 2 children and 2 parents and that the fraction of children of Swiss parents and of foreign parents, who are not allowed to vote, do not differ. Thirty-four percent of the population allowed to vote are aged between 30 and 50 . It seems reasonable that about $50 \%$ of those have children of school age.
}

Parents are on average significantly less likely to vote yes in the post-treatment period. The estimate of interest, i.e., Cant. with regulation $\times$ parent $\times$ post, shows that approval rates of parents in cantons with regulation do not differ from approval rates of the rest of the population in cantons with regulation in the post treatment period. This points to the positive effect on attitudes towards policies facilitating maternal employment not solely being driven by affected parents, but by the population at large.

This analysis has several limitations, the most obvious being that I cannot distinguish between the two treatment margins, the provision and the regulation effect. If within the treated cantons, affected parents not only experience a more positive effect on approval rates from the regulation, but also a more negative effect due to the costs of the provision, this would also result with an estimate of zero. I therefore use another variable available in the post-vote survey data: the response to the question whether Switzerland should actively promote gender equality. This variable reflects attitudes towards policies promoting maternal employment, while not being subject to the costs issue. Specifications (3) and (4) show the results using this variable as the dependent variable. First, it shows that individuals in cantons with regulation are significantly more likely to be in favor of promoting gender equality in the post-treatment period, controlling for pre-treatment differences (estimate on cant. with regulation $\times$ post), reemphasizing the positive effect on gender attitudes in treated regions. Second, this positive change is not driven by parents, i.e., by the group directly benefitting from the introduction of lunchtime of after-school care. While the evidence remains suggestive, it overall points to the positive effect on approval rates being driven by the whole population rather than only by affected parents.

\subsection{Voter composition}

As there are usually a number of bills voted upon on the same day, the entirety of bills will determine turnout and voter composition. General differences in voter composition or voter preferences in the treated and control municipalities are controlled for by the inclusion of municipality fixed effects in the model. Those do therefore not cause a bias. General changes in voter composition between ballots taking place in all municipalities do not cause a bias, either, since they are controlled for by the use of ballot fixed effects. However, if the bills voted upon on the same day as the family policy related bills affect voter composition in the treated municipalities differently than voter composition in the control municipalities, while at the same time voting yes for one bill is correlated to voting yes for another, this will bias the estimates. 
Table 3 DiD estimates using post-vote survey data: effect of lunchtime and after-school care on vote outcomes and attitudes towards gender equality

\begin{tabular}{|c|c|c|c|c|}
\hline \multirow[t]{2}{*}{ Dependent variable } & \multicolumn{2}{|l|}{ Yes } & \multicolumn{2}{|c|}{ Gender equality } \\
\hline & (1) & (2) & (3) & (4) \\
\hline \multirow[t]{2}{*}{ Cant. with regulation $\times$ post } & -0.006 & -0.015 & $0.166^{* * *}$ & $0.152^{* *}$ \\
\hline & $(0.050)$ & $(0.059)$ & $(0.051)$ & $(0.060)$ \\
\hline \multirow[t]{2}{*}{ Parent } & & 0.053 & & 0.057 \\
\hline & & $(0.054)$ & & $(0.057)$ \\
\hline \multirow[t]{2}{*}{ Cant. with regulation $\times$ parent } & & 0.069 & & -0.011 \\
\hline & & $(0.082)$ & & $(0.084)$ \\
\hline \multirow[t]{2}{*}{ Parent $\times$ post } & & $-0.173^{* *}$ & & 0.013 \\
\hline & & $(0.076)$ & & $(0.078)$ \\
\hline \multirow[t]{2}{*}{ Cant. with regulation $\times$ parent $\times$ post } & & 0.009 & & 0.030 \\
\hline & & $(0.111)$ & & $(0.113)$ \\
\hline Ballot FE & Yes & Yes & Yes & Yes \\
\hline Canton FE & Yes & Yes & Yes & Yes \\
\hline Number of observations & 1476 & 1476 & 1476 & 1476 \\
\hline R-squared & 0.09 & 0.10 & 0.03 & 0.03 \\
\hline
\end{tabular}

This table presents the results of the estimations using post-vote surveys. In the first two specifications, the dependent variable is Yes and takes value 1 if an individual stated they voted yes in the post-vote survey and 0 otherwise. In specifications (3) and (4), the dependent variable is Gender equality and takes value 1 if an individual stated they are in favor of Switzerland actively promoting gender equality and 0 otherwise. Cant. with regulation $\times$ parent $\times$ post shows the differential change in the dependent variable of parents compared to non-parents in cantons with regulation in the post period. Only data of individuals living in cantons used for the main analysis are used for the estimation. Individuals living in municipalities with a population of more than 100,000 are excluded from the sample to match the sample used for the rest of the analyses. Ballot FE and Canton FE are used in all specifications. I cannot introduce municipality FE as in the rest of the analyses as there is no municipality identifier in the post-vote survey. The numbers in parentheses show robust standard errors. ${ }^{*} p<0.10,{ }^{* *} p<0.05,{ }^{* * *} p<0.01$

A differential change in voter composition in the treatment and control groups could occur if there were different policies in place in the treatment and control group, which are unrelated to the treatment considered here but would affect voter composition differentially. For the estimate of the provision margin to be biased by the composite of bills voted upon on the same day, a policy would need to be set at the municipal level and affect municipalities introducing lunchtime and after-school care differently from municipalities which do not within the same canton, which I deem highly unlikely. There is more concern considering the regulation margin, since this is defined across and not within cantons. I discuss the highest-turnout bills, the bills most likely to determine voter composition, voted upon on the same day as family policy related topics in more detail to see whether this is a concern. On the date of the first family policy related ballot in 1999, the bill considered had the highest turnout, which is why I additionally consider the bill with the next highest turnout, which was a bill concerning medical prescription of heroin. In 2004, the highest-turnout bill was a bill concerning birthright citizenship for children of foreigners of the second generation. In March 2013, it was a bill concerning limitations to the salaries of executive and administrative board members, and in November 2013, it was a bill demanding that within the same company, the maximum salary must not exceed the minimum salary by more than twelvefold. All of these bills are described in detail in Appendix A.1.

Within the sample of municipalities used for the analysis, the correlations between the family policy bill and the highest turnout bill taking place on the same day are 0.37 for the first date, 0.87 for the second date, 0.19 for the third date, and -0.17 for the last date. Except for the bills voted upon on the second date, the correlation between vote shares for one bill and vote shares for another is rather weak. In those cases, it is therefore unlikely that the effects found in this paper are driven by changes in voter composition brought about by other bills voted upon on the same day.

Since the strong correlation between approval rates for the second ballot, i.e., between the second bill on maternity leave considered for the analysis and the bill concerning birthright citizenship for children of foreigners of the second generation has the potential of creating a bias, I want to discuss this in more detail. The opposing side mainly argued that the bill's goal was so statistically embellish the true share of foreigners in Switzerland and that birthright citizenship was to be opposed on principle. Policies in place in some cantons, while not in 


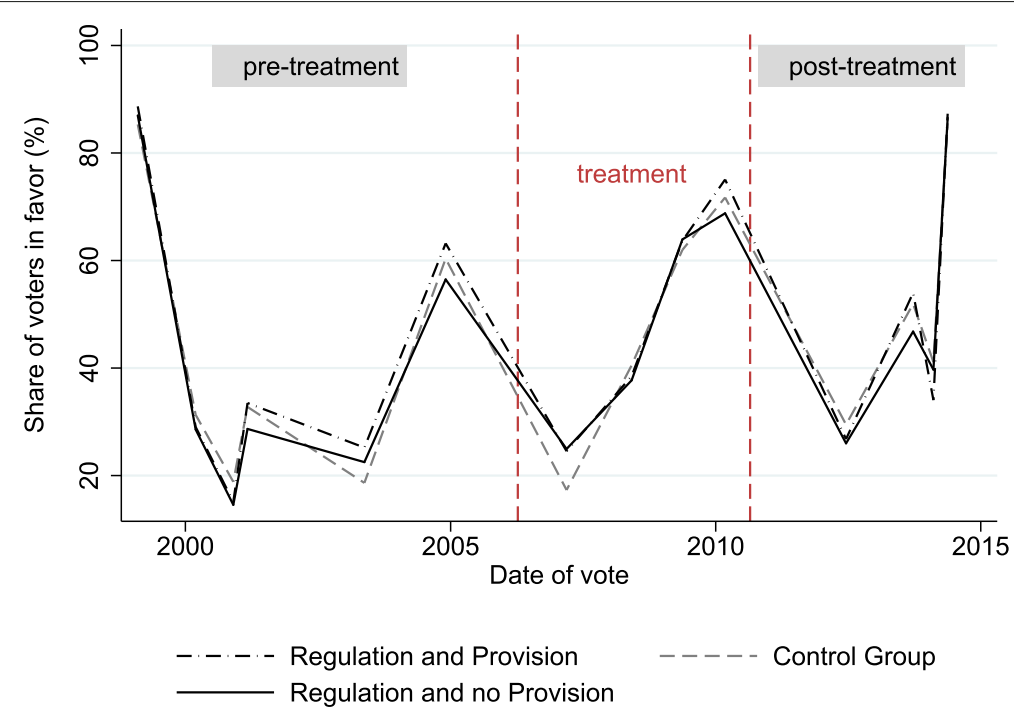

Fig. 8 Vote outcomes of 14 bills on healthcare-related topics in the municipalities with no regulation (mun. in the control cantons), municipalities with regulation but no provision, and municipalities with regulation and provision. The results displayed show population weighted means in vote outcomes for each of the three groups

others, were no argument brought forward by the opposing side. However, 14 cantons already had related policies for facilitated naturalization for adolescents in place, while 12 did not. Among the cantons with facilitated naturalization were three cantons used for the analysis, the cantons of Bern, Zurich, and $\mathrm{Zug}^{26}$. If voters in favor of facilitated naturalization, but who deemed the policies in place sufficient, did not turn out in cantons which already had facilitated naturalization, this would lead to a different voter composition in the treated cantons than in the control cantons. However, the correlation between facilitated naturalization in place and voter turnout is very weak $(-0.13)$ and thus unlikely to cause a bias.

While a differential change in voter composition between treated and control municipalities might theoretically pose a threat to the identification, I conclude that it is unlikely to be the case here. For each ballot date considered in the analysis, the correlation between approval rates for the family policy related bill and the approval rate of the highest-turnout bill seems to be rather weak except for the 2004 ballot. However, it is unlikely that a policy in place affected voter composition in treated and control municipalities differentially.

\subsection{Placebo test}

As a robustness test, I use vote outcomes of ballots unrelated to family policy to show that the approach I apply

${ }^{26}$ The cantons with facilitated naturalization were AR, BS, BE, FR, GE, GL, GR, JU, NE, SO, TI, VD, ZH, and ZG. generally works and to make sure the results are not driven by differing trends of treatment and control groups in general. One of the topics voted upon most frequently are healthcare-related bills. These thus offer a good opportunity to look at general trends in vote outcomes between the three groups. Vote outcomes of all 14 ballots on healthcare-related topics taking place between 1999 and 2014 are displayed in Fig. 8.

Figure 8 shows population weighted means of vote outcome for the three groups, municipalities in the control cantons, municipalities in the cantons with regulation concerning lunchtime and after-school care with actual provision, and municipalities in the cantons with regulation which do not introduce lunchtime or after-school care. The sample is restricted to municipalities which did not have lunchtime or after-school care in 2004 to mirror the sample used for the main analysis. The graph shows no systematic differences in vote outcomes between the three groups: While there are divergences for some ballots, these are small and do not seem to follow any systematic pattern.

I repeat the analysis of family policy bills, now using health bills. I thereby use all referenda on healthrelated bills taking place between 1999 and 2004 for the pre-treatment period and between 2010 and 2014 for the post-treatment period. For easier comparability, I focus on referenda. All referenda are proposals of the parliament, with a majority of the parliament and the federal council already in favor of the bill. This leaves me with a total of six bills that are for instance on an 
Table 4 Effect of lunchtime and after-school care on vote outcomes on healthcare-related topics

\begin{tabular}{llllll}
\hline & $\mathbf{( 1 )}$ & $\mathbf{( 2 )}$ & $\mathbf{( 3 )}$ & $\mathbf{( 4 )}$ & $\mathbf{( 5 )}$ \\
\hline Provision & -0.43 & 0.49 & 0.12 & 0.26 & 0.06 \\
& $(0.413)$ & $(0.396)$ & $(0.404)$ & $(0.401)$ & $(0.408)$ \\
Regulation & $-1.53^{* * *}$ & $-1.32^{*}$ & -0.26 & & \\
& $(0.372)$ & $(0.759)$ & $(0.732)$ & & \\
Municipality FE & Yes & Yes & Yes & Yes & Yes \\
Ballot FE & Yes & Yes & Yes & Yes & Yes \\
Inc. tax & No & Yes & Yes & No & No \\
Covariates & No & No & Yes & No & Yes \\
Canton x ballot FE & No & No & No & Yes & Yes \\
Number of mun. & 915 & 915 & 915 & 915 & 915 \\
Number of obs. & 5486 & 5486 & 5486 & 5486 & 5486 \\
\hline
\end{tabular}

This table presents the DiD estimate, $\hat{\gamma_{1}}$ and $\hat{\gamma_{2}}$, of Eq. 1 at the municipal level. Instead of using family policy related ballots, totally independent ballots taking place on the same day are used for the post treatment period. The regulation coefficient shows the differential change in vote outcomes of municipalities in cantons with regulation compared to municipalities in cantons without regulation regarding lunchtime and after-school care in public schools. The provision coefficient estimates the differential change in vote outcomes in municipalities which introduce lunchtime and after-school care as a consequence of the new regulation compared to those that do not. For the three baseline specifications, only municipalities with no childcare in 2004 are included. For the subsample specifications only municipalities where a majority of voters voted against maternity leave and that did not have lunchtime or after-school care prior to the introduction of the new regulation are included, i.e., municipalities which did not display positive attitudes towards an expansion of public investment encouraging maternal employment before the new regulation regarding lunchtime and after-school care was introduced. The numbers in parentheses show the standard errors, clustered at the municipal level. In all specifications, population weights are applied to account for the fact, that municipalities differ in their size. ${ }^{*} p<0.10,{ }^{* *} p<0.05,{ }^{* * *} p<0.01$

amendment of the law concerning transplantation medicine or stem cell research. The bills are described in detail in Appendix A.1.

Table 4 shows the results of estimating Eq. 1 using approval rates for healthcare related bills as the dependent variable. Specification (1) shows small and negative correlation between provision and approval rates, which is not significant at any conventional level. Albeit more than 6 times smaller than in the main analysis, there is also a negative correlation between regulation and approval rates for healthcare related bills, which is highly significant. This might indicate a general bias towards the status quo after tax increases. Once I control for cantonal taxes for some incomes and family types, the estimate decreases in size in absolute terms, as shown in specification (2) and becomes very close to zero when I further add the covariates described above. These results indicate that the tax increases in the cantons of Bern and Zurich compared to the control cantons are reflected in voters being more likely to vote for the status quo. I would therefore generally hesitate to interpret the regulation effect as causal, since I cannot fully attribute the changes in the cantons of Bern and Zurich compared to the control cantons to the introduction of the regulation. On the other hand, the estimate on provision is very small and insignificant in all specifications when approval rates of healthcarerelated bills are used as the dependent variable. This adds additional validity to the approach and the conclusion that these changes within cantons can in fact be attributed to the introduction of lunchtime and after-school care.

\section{Conclusion}

Many OECD countries devote considerable resources to the provision of public childcare services. The main goal of such efforts is to promote gender equality in employment. As recent literature indicates, the main reason behind the different impacts of children on employment patterns across countries are likely related to gender norms and attitudes towards working mothers (see, e.g., Kleven et al. 2019).

This paper addresses the question whether childcare institutions affect individuals' attitudes towards working mothers. I find that the exogenous introduction of lunchtime and after-school care at public schools increases voters' support of policies by up to 3 percentage points and already in a rather short term (3 years after the introduction). The effect does not seem to be driven by affected parents, but rather by the population as a whole, which points to a true change in preferences towards policies promoting maternal employment. This positive effect is, however, decreasing in the costs of new institutions: Voters seem to be very aware that new institutions will give rise to increased public expenditures, which reduces voters' support for additional policies promoting maternal employment. Nevertheless, my results show that in addition to the effect on maternal employment, childcare institutions have the potential of changing attitudes of individuals who are not directly exposed, and therefore of changing norms concerning parenthood. This might also contribute to the explanation why countries with a long tradition of parental leave and public childcare have considerably more positive attitudes towards working mothers, since there is not only the direct effect of the policies but also the indirect effect through individuals' norms. 


\section{A Appendix}

A.1 Additional information on ballots

Family policy-related ballots

(a) Maternity Leave. It asks "State Children?" and recommends to vote no.

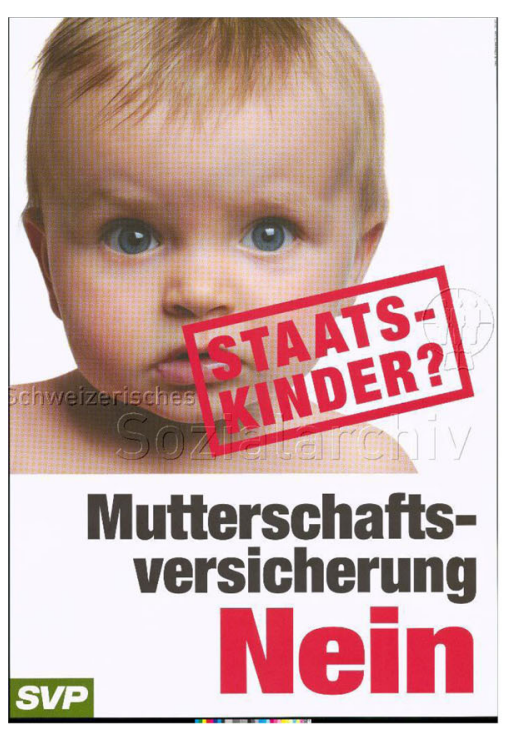

(b) Family Initiative. Implies crying children if voters support traditional family model and vice versa.

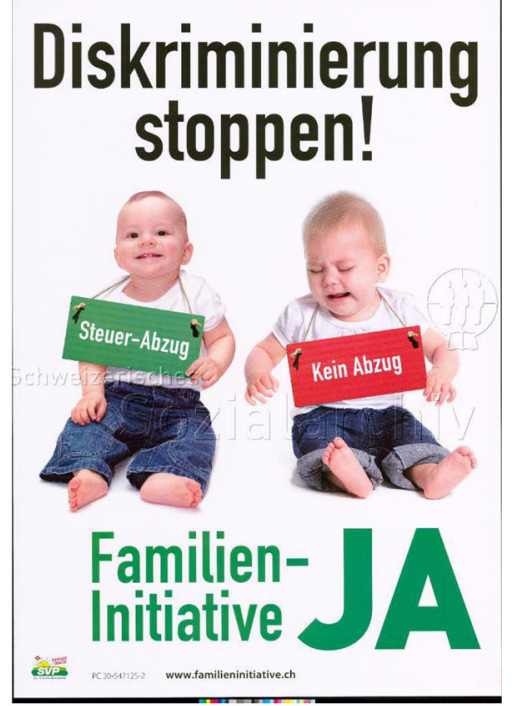

(c) Family Policy. It asks "State Children?" and recommends to vote no.

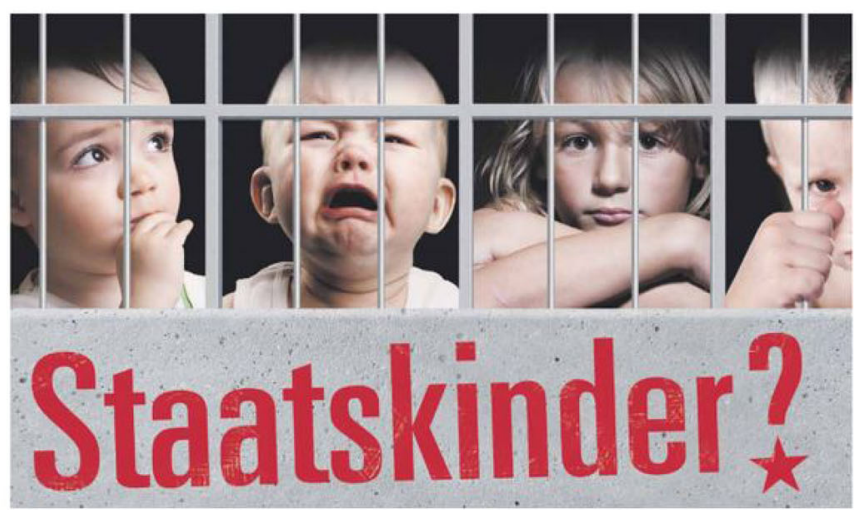

\section{Nein zur Verstaatlichung der Kinder}

Fig. 9 Campaigns by the Swiss People Party 


\section{Highest-turnout bills voted upon on the same day as family policy related ballots}

\section{June 1999}

Medical prescription of heroin.

- The bill proposed the medical prescription of heroin for heavily addicted patients.

- Legislative referendum

- Approval rate: $54.4 \%$; turnout: $45.74 \%$

- The bill stated that for a small group of heavily addicted, the medical prescription of heroin offers a necessary addition to their treatment, with positive effects on their health condition and social integration. It should therefore be permitted for doctors to prescribe heroin to addicted individuals. Such a prescription would only be available to individuals, who had been addicted for a minimum of 2 years and who had unsuccessfully completed two different therapies.

- Recommendation by the federal council and parliament: the federal council and the parliament recommend the adoption of the proposed bill.

\section{October 2003}

Citizenship for foreigners of the third generation

- The ballot was concerning birthright citizenship for the third generation

- Constitutional referendum

- Approval rate: $48.4 \%$; turnout: $53.83 \%$

- The bill wanted to implement a constitutional change. Children of foreigners of the second generation should receive birthright citizenship. In detail, if a child is borne in Switzerland and if at least one parent attended a minimum of 5 years of compulsory schooling in Switzerland or if at least one parent was in possession of a residence permit for a minimum of 5 years on the date of birth of the child, the child receives birthright citizenship.

- Recommendation by the federal council and parliament: the federal council and the parliament recommend the adoption of the proposed bill.

\section{March 2013}

Bill against corporate rip-off

- The ballot was concerning limitations to the salaries of executive and administrative board members

- Initiative

- Approval rate: $68.0 \%$; turnout: $46.74 \%$

- The initiative's purpose was to set limits to the salaries of executive and administrative board members of market-listed companies. Particularly, this goal was to be achieved by implementing three new rules. First, salaries of executive and administrative board members must be approved by the general assembly. Second, tenure of administrative board members is limited to 1 year. Third, remunerations like termination pay or premium for the sale of a firm are prohibited. Any violation of these rules will be punished.

- Recommendation by the federal council and parliament: The federal council and the council of states recommend to reject the initiative. The national council decided not to make any recommendations.

24 November 2013

1:12 - for fair salaries

- The ballot was concerning the distribution of salaries within a company

- Initiative

- Approval rate: $34.7 \%$; turnout: $53.63 \%$

- The initiative demanded that within the same company, the maximum salary must not exceed the minimum salary by more than twelvefold.

- Recommendation by the federal council and parliament: the federal council and the parliament recommend to reject the initiative.

\section{Ballots related to health topics}

\section{February 1999}

- The ballot was concerning transplantation medicine.

- Constitutional referendum

- Approval rate: $87.8 \%$; turnout: $37.98 \%$

- The question was whether an article concerning transplantation medicine should be added to the constitution. The problem was that even though hospitals had been successfully transplanting organs, tissue, and cells for more than 30 years, there was no federal law regulating these practices. There were some cantonal laws in place but those varied substantially between cantons and were missing important aspects. In other cantons, there was no regulation whatsoever. The new constitutional article was going to include regulations on how the federation planned to protect human dignity, personality, and health of the patient and the donor, as well as how organs should be allocated rightfully. Also, the article was to prevent malpractice by forbidding trade of organs and targeted donations.

\section{November 2004}

- Ballot concerning stem cell research

- Approval rate: $66.4 \%$; turnout: $37.02 \%$

- Legislative referendum 
- The bill proposed a new law concerning research with stem cells. The new law was going to make embryonal stem cell research possible in Switzerland. Among other things, it was going to require each research project to be evaluated concerning ethical and scientific criteria. Also, stem cells for research projects are only allowed to be harvested if derived from embryos which developed from eggs fertilized in vitro, but which could not be used for a pregnancy.

\section{March 2010}

- Ballot concerning research with human subjects

- Approval rate: $77.2 \%$; turnout: $45.49 \%$

- Constitutional referendum

- The bill proposed a constitutional article regulating research with human subjects. At the federal level, there are only regulations concerning some parts of this research. Most of the responsibilities are at the cantonal level, where there are large disparities, with some cantons not having any regulations in place whatsoever. The new article establishes that research with human subjects can only be undertaken with their full consent and and only allows research with children or other vulnerable individuals only in case that the findings cannot be realized with consenting adults. Furthermore, the article stipulates that the risks and strain on participants must be in balance with the benefit of the research project. Also, the article establishes ethical guidelines and guidelines concerning the protection of participants' dignity.

\section{June 2012}

- Ballot concerning statutory health insurance

- Approval rate: $24.0 \%$; turnout: $38.65 \%$

- Legislative referendum

- Every person living in Switzerland must have health insurance. One can choose between different insurance policies, differing in the deductible and restrictions concerning the free choice of doctor or hospital and accordingly the insurance premiums. The bill proposed the implementation of new healthcare networks with doctors, pharmacies, hospitals, nursing homes, and midwives. Patients would be treated within these networks, which would promote better cooperation between healthcare providers.

\section{September 2013}

- Ballot concerning amendment of epidemics law

- Approval rate: $60 \%$; turnout: $46.76 \%$

- Legislative referendum
- The currently valid law concerning epidemic diseases dated back to 1970 and did not provide sufficient protection against transmittable diseases. The new law was going to provide the ground on which transmittable diseases could be identified in a timely manner and fought efficiently, and new measures against the increasing problem of antibiotic resistance implemented. Also, responsibilities would be more clearly assigned between cantonal and federal governments.

\section{May 2014}

- Ballot concerning primary health care

- Approval rate: $88.1 \%$; turnout: $55.85 \%$

- Constitutional referendum (counter proposal to a popular initiative demanding the support of primary care physicians)

- The proposed constitutional article was going to promote primary health care in general and specifically primary care physicians. The parliament proposed this article as a reaction to the initiative "Yes to primary health care" (Ja zur Hausarztmedizin), submitted by primary care physicians. As a reaction to the proposed article, the physicians withdrew their initiative.

\section{A.2 Tables and figures Post-vote survey}

In order to gain some insight into how personal characteristics and attitudes towards gender equality are reflected in vote outcomes, I use data of post-vote surveys provided by FORS Lausanne. The post-vote surveys are conducted after each federal ballot with a representative sample of about 1500 eligible voters and take place in the 2 to 3 weeks following a ballot. Surveyed topics include individual socioeconomic characteristics, political opinions and habits, as well as various aspects related to the decision to vote on certain topics.

The tables in this section show statistics from the post vote surveys, conducted after each vote. Data from individuals from all parts of Switzerland are considered. Table 5 shows descriptive statistics of the surveys conducted after each of the four ballots considered in this paper. The table further indicates the gender difference, as well as whether the difference is statistically significant. The table shows that the shares of men and women with tertiary education have increased over time, but while the increase was rather small for men, the fraction of women with tertiary education has increased from $6.6 \%$ in 1999 to about $15 \%$ in 2013. Nevertheless, the gender difference is still more than $10 \mathrm{ppt}$ and remains 
Table 5 Descriptive statistics of post-vote surveys

\begin{tabular}{|c|c|c|c|c|c|c|}
\hline & Men & Women & Diff. & Std. error & Obs. men & Obs. women \\
\hline \multicolumn{7}{|l|}{ Maternity leave I } \\
\hline Yes share & 0.339 & 0.380 & -0.041 & 0.040 & 236 & 358 \\
\hline Tertiary educ. & 0.203 & 0.067 & $0.136^{* * *}$ & 0.029 & 236 & 358 \\
\hline Employed & 0.581 & 0.430 & $0.150^{* * *}$ & 0.042 & 236 & 358 \\
\hline Age/10 & 5.374 & 5.291 & 0.083 & 0.139 & 236 & 358 \\
\hline Retired & 0.297 & 0.246 & 0.051 & 0.038 & 236 & 358 \\
\hline Married & 0.708 & 0.656 & 0.051 & 0.039 & 236 & 358 \\
\hline Income $<$ CHF 5,000 & 0.335 & 0.413 & $-0.079^{*}$ & 0.040 & 236 & 358 \\
\hline Income CHF 5,000 - 11,000 & 0.492 & 0.455 & 0.036 & 0.042 & 236 & 358 \\
\hline Income > CHF 11,000 & 0.174 & 0.131 & 0.042 & 0.031 & 236 & 358 \\
\hline \multicolumn{7}{|l|}{ Maternity leave II } \\
\hline Yes share & 0.656 & 0.604 & 0.052 & 0.044 & 209 & 270 \\
\hline Tertiary educ. & 0.239 & 0.126 & $0.113^{* * *}$ & 0.036 & 209 & 270 \\
\hline Employed & 0.641 & 0.489 & $0.152^{* * *}$ & 0.045 & 209 & 270 \\
\hline Age/10 & 5.062 & 5.386 & $-0.324^{* *}$ & 0.161 & 209 & 270 \\
\hline Retired & 0.234 & 0.270 & -0.036 & 0.040 & 209 & 270 \\
\hline Married & 0.598 & 0.619 & -0.020 & 0.045 & 209 & 270 \\
\hline Income $<$ CHF 5,000 & 0.368 & 0.437 & -0.069 & 0.045 & 209 & 270 \\
\hline Income CHF 5,000 - 11,000 & 0.445 & 0.419 & 0.026 & 0.046 & 209 & 270 \\
\hline Income $>$ CHF 11,000 & 0.187 & 0.144 & 0.042 & 0.034 & 209 & 270 \\
\hline \multicolumn{7}{|l|}{ Family policy } \\
\hline Yes share & 0.469 & 0.507 & -0.037 & 0.045 & 213 & 304 \\
\hline Tertiary educ. & 0.277 & 0.168 & $0.109^{* * *}$ & 0.037 & 213 & 304 \\
\hline Employed & 0.563 & 0.454 & $0.109^{* *}$ & 0.044 & 213 & 304 \\
\hline Age/10 & 5.571 & 5.703 & -0.132 & 0.137 & 213 & 304 \\
\hline Retired & 0.291 & 0.359 & -0.067 & 0.042 & 213 & 304 \\
\hline Married & 0.648 & 0.599 & 0.049 & 0.043 & 213 & 304 \\
\hline Income $<$ CHF 5,000 & 0.315 & 0.378 & -0.064 & 0.042 & 213 & 304 \\
\hline Income CHF 5,000 - 11,000 & 0.610 & 0.562 & 0.048 & 0.044 & 213 & 304 \\
\hline Income > CHF 11,000 & 0.075 & 0.059 & 0.016 & 0.023 & 213 & 304 \\
\hline \multicolumn{7}{|l|}{ Family initiative } \\
\hline Yes share & 0.522 & 0.592 & -0.070 & 0.045 & 203 & 294 \\
\hline Tertiary educ. & 0.256 & 0.136 & $0.120^{* * *}$ & 0.037 & 203 & 294 \\
\hline Employed & 0.547 & 0.401 & $0.145^{* * *}$ & 0.045 & 203 & 294 \\
\hline Age/10 & 5.729 & 5.691 & 0.037 & 0.143 & 203 & 294 \\
\hline Retired & 0.296 & 0.378 & $-0.082^{*}$ & 0.043 & 203 & 294 \\
\hline Married & 0.704 & 0.588 & $0.116^{* * *}$ & 0.043 & 203 & 294 \\
\hline Income $<$ CHF 5,000 & 0.296 & 0.435 & $-0.140^{* * *}$ & 0.043 & 203 & 294 \\
\hline Income CHF 5,000 - 11,000 & 0.601 & 0.507 & $0.094^{* *}$ & 0.045 & 203 & 294 \\
\hline Income $>$ CHF 11,000 & 0.103 & 0.058 & $0.046^{*}$ & 0.025 & 203 & 294 \\
\hline
\end{tabular}

This table shows descriptive statistics for the four ballots considered, as well as whether there is a significant difference between men and women 
Table 6 Post-vote survey: correlation between the probability to vote yes and attitudes towards gender equality

\begin{tabular}{|c|c|c|c|c|}
\hline Bill & Mat. leave I & Mat. leave II & Fam. pol. & Fam. init \\
\hline \multirow[t]{2}{*}{ Gender equality } & $0.17^{* * *}$ & $0.19^{* * *}$ & $0.17^{* * *}$ & 0.07 \\
\hline & $(0.04)$ & $(0.04)$ & $(0.04)$ & $(0.05)$ \\
\hline \multirow[t]{2}{*}{ Age/10 } & $-0.22^{* *}$ & 0.00 & -0.04 & $0.20^{* *}$ \\
\hline & $(0.10)$ & $(0.09)$ & $(0.10)$ & $(0.10)$ \\
\hline \multirow[t]{2}{*}{$\mathrm{Age}^{2}$} & $0.02^{*}$ & -0.00 & 0.00 & -0.01 \\
\hline & $(0.01)$ & $(0.01)$ & $(0.01)$ & $(0.01)$ \\
\hline \multirow[t]{2}{*}{ Tertiary educ. } & 0.03 & $0.11^{*}$ & $0.09^{*}$ & -0.00 \\
\hline & $(0.06)$ & $(0.06)$ & $(0.05)$ & $(0.06)$ \\
\hline \multirow[t]{2}{*}{ Female } & 0.07 & -0.02 & 0.05 & $0.08^{*}$ \\
\hline & $(0.04)$ & $(0.04)$ & $(0.05)$ & $(0.05)$ \\
\hline \multirow[t]{2}{*}{ Employed } & $0.11^{* *}$ & 0.02 & 0.00 & $0.12^{* *}$ \\
\hline & $(0.05)$ & $(0.05)$ & $(0.06)$ & $(0.06)$ \\
\hline \multirow[t]{2}{*}{ Income CHF 5, $000-11,000$} & -0.03 & -0.00 & -0.00 & $0.09^{*}$ \\
\hline & $(0.05)$ & $(0.05)$ & $(0.05)$ & $(0.05)$ \\
\hline \multirow[t]{2}{*}{ Income > CHF 11,000 } & -0.02 & -0.02 & -0.14 & $0.20^{* *}$ \\
\hline & $(0.06)$ & $(0.07)$ & $(0.10)$ & $(0.09)$ \\
\hline \multirow[t]{2}{*}{ Retired } & -0.01 & -0.02 & 0.00 & 0.13 \\
\hline & $(0.09)$ & $(0.10)$ & $(0.09)$ & $(0.09)$ \\
\hline \multirow[t]{2}{*}{ Married } & 0.01 & 0.00 & $0.11^{* *}$ & $-0.14^{* * *}$ \\
\hline & $(0.05)$ & $(0.05)$ & $(0.05)$ & $(0.05)$ \\
\hline \multirow[t]{2}{*}{ Constant } & $0.79^{* * *}$ & $0.62^{* * *}$ & $0.46^{*}$ & -0.19 \\
\hline & $(0.23)$ & $(0.20)$ & $(0.26)$ & $(0.24)$ \\
\hline Number of observations & 569 & 469 & 511 & 490 \\
\hline R-square & 0.07 & 0.08 & 0.05 & 0.06 \\
\hline
\end{tabular}

Correlation between the probability to vote "Yes" in the four bills considered and personal attitudes towards gender equality. Calculations draw on post-vote surveys conducted with a random sample of Swiss voters. The table shows that attitudes towards gender equality are an important driver of vote results in the ballots considered. Gender equality is a dummy variable based on the question "Are you in favor of Switzerland actively promoting female equality to men (survey question A91h $\leq 3$ ) or in favor of Switzerland favoring neither men nor women (survey question $3<A 91<=6$ )

statistically significant for all four ballots considered. The only other variable which is significant in all four ballots is employment: men are about 14ppt more likely to be employed than women. The employment fractions seem very low at first sight. However, in the post vote survey, everybody who does not have any formal employment is considered not employed. This includes retired individuals, who constitute about one third of the total sample.

All the variables displayed in Table 7 are also considered in the regressions in Table 5. The estimates show a significant positive effect of age and whether an individual is employed on the probability that somebody votes yes.
In the maternity leave ballot in 1999 , older people were less likely to vote yes. In the 2004 maternity leave and the family policy ballot, there is a positive correlation between tertiary education and the probability to vote yes. However, the biggest correlation is found between party affinity and the probability to vote yes: voters describing themselves as affiliated with the Social Party (SP), the biggest left wing party in $\mathrm{CH}$, are $21 \%$ to $42 \%$ more likely to vote yes, whereas voters describing themselves as affiliated with the Swiss People Party (SVP), the biggest right wing party, are $35 \%$ to $42 \%$ less likely to vote yes. Affiliation with other parties does not have any correlation with voting behavior. 
Table 7 Post-vote survey: correlation between the probability to vote yes and certain personal characteristics

\begin{tabular}{|c|c|c|c|c|c|}
\hline Bill & Mat. leave I & Mat. leave II & Fam. pol. & Fam. init. & All \\
\hline \multirow[t]{2}{*}{ Age/10 } & $-0.25^{* * *}$ & -0.06 & -0.01 & $0.18^{*}$ & -0.05 \\
\hline & $(0.09)$ & $(0.08)$ & $(0.10)$ & $(0.09)$ & $(0.04)$ \\
\hline \multirow[t]{2}{*}{$\mathrm{Age}^{2}$} & $0.02^{* *}$ & 0.00 & -0.00 & -0.01 & 0.00 \\
\hline & $(0.01)$ & $(0.01)$ & $(0.01)$ & $(0.01)$ & $(0.00)$ \\
\hline \multirow[t]{2}{*}{ Tertiary educ. } & 0.03 & $0.09^{*}$ & $0.11^{* *}$ & 0.00 & $0.06^{* *}$ \\
\hline & $(0.06)$ & $(0.05)$ & $(0.05)$ & $(0.06)$ & $(0.03)$ \\
\hline \multirow[t]{2}{*}{ Female } & 0.04 & -0.02 & 0.04 & 0.06 & 0.03 \\
\hline & $(0.04)$ & $(0.04)$ & $(0.04)$ & $(0.05)$ & $(0.02)$ \\
\hline \multirow[t]{2}{*}{ Employed } & $0.08^{*}$ & 0.03 & 0.01 & $0.14^{* *}$ & $0.07^{* * *}$ \\
\hline & $(0.05)$ & $(0.05)$ & $(0.06)$ & $(0.06)$ & $(0.03)$ \\
\hline \multirow[t]{2}{*}{ Income CHF 5,000 - 11,000 } & -0.04 & -0.00 & -0.01 & 0.05 & -0.01 \\
\hline & $(0.05)$ & $(0.05)$ & $(0.05)$ & $(0.05)$ & $(0.02)$ \\
\hline \multirow[t]{2}{*}{ Income > CHF 11,000 } & -0.05 & -0.02 & $-0.15^{*}$ & $0.18^{* *}$ & -0.02 \\
\hline & $(0.06)$ & $(0.06)$ & $(0.09)$ & $(0.08)$ & $(0.03)$ \\
\hline \multirow[t]{2}{*}{ Retired } & -0.03 & -0.02 & 0.03 & $0.16^{*}$ & 0.06 \\
\hline & $(0.09)$ & $(0.09)$ & $(0.09)$ & $(0.09)$ & $(0.04)$ \\
\hline \multirow[t]{2}{*}{ Married } & 0.02 & 0.02 & $0.08^{*}$ & $-0.11^{* *}$ & 0.00 \\
\hline & $(0.04)$ & $(0.04)$ & $(0.05)$ & $(0.05)$ & $(0.02)$ \\
\hline \multirow[t]{2}{*}{ Affinity CVP } & -0.02 & 0.14 & 0.11 & 0.10 & 0.07 \\
\hline & $(0.07)$ & $(0.11)$ & $(0.08)$ & $(0.09)$ & $(0.04)$ \\
\hline \multirow[t]{2}{*}{ Affinity FDP } & 0.02 & -0.03 & 0.05 & -0.01 & 0.01 \\
\hline & $(0.08)$ & $(0.08)$ & $(0.07)$ & $(0.09)$ & $(0.04)$ \\
\hline \multirow[t]{2}{*}{ Affinity SP } & $0.42^{* * *}$ & $0.34^{* * *}$ & $0.22^{* * *}$ & $0.21^{* * *}$ & $0.29^{* * *}$ \\
\hline & $(0.06)$ & $(0.04)$ & $(0.06)$ & $(0.06)$ & $(0.03)$ \\
\hline \multirow[t]{2}{*}{ Affinity SVP } & $-0.31^{* * *}$ & $-0.42^{* * *}$ & $-0.25^{* * *}$ & $-0.27^{* * *}$ & $-0.32^{* * *}$ \\
\hline & $(0.04)$ & $(0.06)$ & $(0.06)$ & $(0.06)$ & $(0.03)$ \\
\hline \multirow[t]{2}{*}{ Constant } & $0.97^{* * *}$ & $0.81^{* * *}$ & $0.49^{* *}$ & -0.08 & $0.46^{* * *}$ \\
\hline & $(0.21)$ & $(0.18)$ & $(0.24)$ & $(0.22)$ & $(0.11)$ \\
\hline Ballot FE & No & No & No & No & Yes \\
\hline Number of observations & 594 & 479 & 517 & 497 & 2087 \\
\hline R-squared & 0.17 & 0.24 & 0.09 & 0.13 & 0.16 \\
\hline
\end{tabular}




\section{Descriptive statistics}

Table 8 Descriptive Statistics

\begin{tabular}{|c|c|c|c|c|c|c|c|c|}
\hline & Mat. Le & & Mat. Le & & Family & & Family & \\
\hline & Mean & SD & Mean & SD & Mean & SD & Mean & SD \\
\hline Regulation and Provis & & & & & & & & \\
\hline Share of Yes votes & 31.41 & (8.13) & 49.15 & $(8.76)$ & 44.05 & $(8.29)$ & 51.88 & $(7.47)$ \\
\hline Tax multiplier & 48.91 & $(57.54)$ & 44.62 & $(53.31)$ & 43.21 & $(51.64)$ & 43.21 & $(51.64)$ \\
\hline Share of SPP voters & 37.69 & $(11.24)$ & 38.26 & $(10.64)$ & 36.10 & $(8.64)$ & 36.10 & $(8.64)$ \\
\hline Share of SP voters & 22.29 & $(6.30)$ & 22.79 & $(6.61)$ & 15.29 & $(4.88)$ & 15.29 & $(4.88)$ \\
\hline Voter turnout & 47.05 & $(5.27)$ & 53.69 & $(6.15)$ & 44.78 & $(6.36)$ & 54.67 & $(7.26)$ \\
\hline Births in $\%$ of pop & 1.06 & $(0.26)$ & 4.80 & $(0.84)$ & 12.37 & $(2.08)$ & 12.37 & $(2.08)$ \\
\hline Deaths in $\%$ of pop & 0.82 & $(0.31)$ & 3.86 & $(1.15)$ & 10.08 & $(3.11)$ & 10.08 & $(3.11)$ \\
\hline Immigrants in \% of pop & 7.49 & $(2.23)$ & 36.18 & $(8.02)$ & 97.61 & $(18.62)$ & 97.61 & $(18.62)$ \\
\hline Emigrants in $\%$ of pop & 7.10 & $(2.09)$ & 33.43 & $(7.14)$ & 89.08 & $(16.96)$ & 89.08 & $(16.96)$ \\
\hline Population in 1000 & 3.78 & $(4.58)$ & 3.93 & $(4.66)$ & 4.32 & (5.19) & 4.32 & (5.19) \\
\hline Number of Mun. & 192 & & 192 & & 192 & & 192 & \\
\hline Regulation and No Pro & & & & & & & & \\
\hline Share of Yes votes & 28.94 & $(11.75)$ & 44.21 & (11.15) & 38.99 & (10.99) & 44.98 & $(8.53)$ \\
\hline Tax multiplier & 20.24 & $(43.07)$ & 18.22 & $(40.08)$ & 17.83 & (39.22) & 17.83 & $(39.22)$ \\
\hline Share of SPP voters & 47.20 & $(12.89)$ & 46.77 & $(12.28)$ & 43.53 & $(10.82)$ & 43.53 & $(10.82)$ \\
\hline Share of SP voters & 19.00 & (8.13) & 18.66 & $(7.94)$ & 12.09 & $(5.55)$ & 12.09 & $(5.55)$ \\
\hline Voter turnout & 46.50 & $(8.25)$ & 50.75 & $(8.41)$ & 43.61 & $(6.82)$ & 55.67 & $(10.40)$ \\
\hline Births in $\%$ of pop & 1.08 & $(0.45)$ & 4.83 & $(1.25)$ & 12.94 & $(2.68)$ & 12.94 & $(2.68)$ \\
\hline Deaths in $\%$ of pop & 0.95 & $(0.54)$ & 4.29 & $(1.32)$ & 11.88 & $(3.32)$ & 11.88 & (3.32) \\
\hline Immigrants in \% of pop & 6.35 & $(2.56)$ & 31.40 & $(8.75)$ & 89.44 & $(20.01)$ & 89.44 & $(20.01)$ \\
\hline Emigrants in \% of pop & 6.40 & $(2.31)$ & 30.60 & $(7.78)$ & 87.71 & (19.29) & 87.71 & $(19.29)$ \\
\hline Population in 1000 & 0.91 & $(0.85)$ & 0.92 & $(0.86)$ & 0.95 & $(0.91)$ & 0.95 & $(0.91)$ \\
\hline Number of Mun. & 234 & & 234 & & 233 & & 233 & \\
\hline No Regulation & & & & & & & & \\
\hline Share of Yes votes & 22.11 & $(6.05)$ & 37.77 & $(8.06)$ & 39.96 & $(6.93)$ & 50.08 & $(6.74)$ \\
\hline Tax multiplier & 121.74 & $(70.71)$ & 116.82 & (63.79) & 104.60 & $(54.56)$ & 104.60 & $(54.56)$ \\
\hline Share of SPP voters & 34.17 & $(10.28)$ & 37.99 & (10.94) & 38.59 & $(9.01)$ & 38.59 & $(9.01)$ \\
\hline Share of SP voters & 13.90 & $(6.92)$ & 15.08 & $(7.53)$ & 13.12 & $(6.31)$ & 13.12 & $(6.31)$ \\
\hline Voter turnout & 47.83 & $(7.65)$ & 55.42 & $(6.77)$ & 46.39 & $(7.54)$ & 53.84 & $(6.33)$ \\
\hline Births in $\%$ of pop & 1.16 & $(0.34)$ & 5.05 & $(1.02)$ & 12.53 & $(2.85)$ & 12.53 & $(2.85)$ \\
\hline Deaths in $\%$ of pop & 0.72 & $(0.28)$ & 3.46 & $(0.95)$ & 8.75 & $(2.62)$ & 8.75 & $(2.62)$ \\
\hline Immigrants in \% of pop & 6.78 & $(2.05)$ & 32.73 & $(7.85)$ & 90.06 & $(24.25)$ & 90.06 & $(24.25)$ \\
\hline Emigrants in \% of pop & 6.63 & $(1.86)$ & 31.08 & $(7.22)$ & 82.12 & $(22.80)$ & 82.12 & $(22.80)$ \\
\hline Population in 1000 & 2.76 & $(3.31)$ & 2.87 & $(3.44)$ & 3.21 & $(3.77)$ & 3.21 & $(3.77)$ \\
\hline Number of Mun. & 453 & & 453 & & 453 & & 453 & \\
\hline
\end{tabular}

Notes: This table shows descriptive statistics for the municipalities included in the main analysis and for each of the three groups (no regulation, regulation and provision, regulation and no provision 


\section{Analysis of covariates}

Table 9 DiD estimates of the introduction of lunchtime and after-school care on covariates

\begin{tabular}{lllll}
\hline Dep. var. & Turnout & Births & Immig. & Emig. \\
& $\mathbf{( 1 )}$ & $\mathbf{( 2 )}$ & $\mathbf{( 3 )}$ & $\mathbf{( 4 )}$ \\
\hline Provision & $-2.02^{* * *}$ & -0.26 & $6.32^{* * *}$ & 1.22 \\
& $(0.54)$ & $(0.21)$ & $(2.00)$ & $(1.97)$ \\
Regulation & $2.64^{* * *}$ & 0.49 & 3.04 & $7.60^{* * *}$ \\
& $(0.41)$ & $(0.30)$ & $(2.33)$ & $(2.17)$ \\
Municipality FE & Yes & Yes & Yes & Yes \\
Ballot FE & Yes & Yes & Yes & Yes \\
Number of Mun. & 915 & 922 & 922 & 922 \\
Number of Obs. & 3658 & 3688 & 3688 & 3688 \\
\hline
\end{tabular}

Notes: This table presents the DiD estimates, $\hat{\gamma}_{1}$ and $\hat{\gamma}_{2}$, of Equation (1), but with variables other than vote outcomes as the dependent variable. The regulation coefficient shows the differential change in these covariates of municipalities in cantons with regulation compared to municipalities in cantons without regulation regarding lunchtime and after-school care in public schools, controlling for the differences in provision within the treated cantons. The provision coefficient estimates the differential change in the covariates in municipalities which introduce lunchtime and after-school care as a consequence of the new regulation compared to those which do not. The numbers in parentheses show the standard errors, clustered at the municipal level. In all specifications, population weights are applied to account for the fact, that municipalities differ in their size. ${ }^{*} p<0.10,{ }^{* *} p<0.05$, *** $p<0.01$

Table 10 DiD estimates of the introduction of lunchtime and after-school care on a set of covariates, including cantonal time trends

\begin{tabular}{llllll}
\hline Dep. var. & $\begin{array}{l}\text { Tax } \\
\text { Multiplier }\end{array}$ & Turnout & Births & Immig. & Emig. \\
& $\mathbf{( 1 )}$ & $\mathbf{( 2 )}$ & $\mathbf{( 3 )}$ & $\mathbf{( 4 )}$ & $\mathbf{( 5 )}$ \\
\hline Provision & 0.45 & $-1.96^{* * *}$ & $-0.49^{*}$ & 2.93 & -1.19 \\
& $(0.63)$ & $(0.66)$ & $(0.27)$ & $(2.06)$ & $(2.16)$ \\
Municipality FE & Yes & Yes & Yes & Yes & Yes \\
Canton x ballot FE & Yes & Yes & Yes & Yes & Yes \\
Number of Mun. & 922 & 915 & 922 & 922 & 922 \\
Number of Obs. & 3688 & 3658 & 3688 & 3688 & 3688 \\
\hline
\end{tabular}

Notes: This table presents the DiD estimates, $\hat{\gamma_{1}}$ and $\hat{\gamma_{2}}$, of Eq (1), but with variables other than vote outcomes as the dependent variable. The regulation coefficient shows the differential change in these covariates of municipalities in cantons with regulation compared to municipalities in cantons without regulation regarding lunchtime and after-school care in public schools, controlling for the differences in provision within the treated cantons. The provision coefficient estimates the differential change in the covariates in municipalities which introduce lunchtime and after-school care as a consequence of the new regulation compared to those which do not. The Regulation coefficient can no longer be identified in the presence of canton $\times$ Ballot FE due to collinearity. The numbers in parentheses show the standard errors, clustered at the municipal level. In all specifications, population weights are applied to account for the fact, that municipalities differ in their size. ${ }^{*} p<0.10,{ }^{* *} p<0.05,{ }^{* * *} p<0.01$
Table 11 DiD estimates: Effect of lunchtime and after-school care on vote outcomes

\begin{tabular}{lllll}
\hline & $(\mathbf{1})$ & $\mathbf{( 2 )}$ & $\mathbf{( 3 )}$ & $\mathbf{( 4 )}$ \\
\hline Provision & $1.58^{* * *}$ & $1.27^{* *}$ & $1.08^{*}$ & 0.82 \\
& $(0.556)$ & $(0.599)$ & $(0.550)$ & $(0.554)$ \\
Regulation & $-8.71^{* * *}$ & $-7.89^{* * *}$ & $-5.77^{* * *}$ & \\
Tax multiplier & $(0.457)$ & $(0.500)$ & $(0.954)$ & \\
Voter turnout & $-0.01^{*}$ & -0.00 & & $0.03^{* *}$ \\
& $(0.006)$ & $(0.006)$ & & $(0.015)$ \\
Births in \% of pop & $-0.27^{* * *}$ & $-0.16^{* * *}$ & $-0.26^{* * *}$ & $-0.26^{* * *}$ \\
& $(0.035)$ & $(0.029)$ & $(0.040)$ & $(0.037)$ \\
Immigrants in \% of pop & $-0.25^{* * *}$ & $-0.14^{* *}$ & $-0.21^{* * *}$ & $-0.26^{* * *}$ \\
& $(0.069)$ & $(0.065)$ & $(0.067)$ & $(0.067)$ \\
Emigrants in \% of pop & $0.12^{* * *}$ & $0.14^{* * *}$ & $0.11^{* * *}$ & $0.09^{* * *}$ \\
& $(0.020)$ & $(0.020)$ & $(0.019)$ & $(0.019)$ \\
Municipality FE & $-0.06^{* * *}$ & $-0.09^{* * *}$ & $-0.05^{* *}$ & $-0.04^{*}$ \\
Ballot FE & $(0.022)$ & $(0.023)$ & $(0.021)$ & $(0.021)$ \\
Inc. tax & Yes & Yes & Yes & Yes \\
Canton x ballot FE & Yes & Yes & Yes & Yes \\
Number of mun. & No & No & Yes & No \\
Number of obs. & No & No & No & Yes \\
\hline Notes This tab pres & 742 & 915 & 915 \\
& 3658 & 2966 & 3658 & 3658 \\
\hline
\end{tabular}

Notes: This table presents the DiD estimates, $\hat{\gamma_{1}}$ and $\hat{\gamma_{2}}$, of Eq. (1). The regulation coefficient shows the differential change in vote outcomes of municipalities in cantons with regulation compared to municipalities in cantons without regulation regarding lunchtime and after-school care in public schools, controlling for the differences in provision within the treated cantons. The provision coefficient estimates the differential change in vote outcomes in municipalities which introduce lunchtime and after-school care as a consequence of the new regulation compared to those which do not. Inc. tax consists of the income tax (cantonal + municipality + church taxes) for singles, married couples with no children, and married couples with two children, each for yearly net incomes of CHF 80,000.-, 100,000.-, 150,000.-, and 200,000.-- In specification (4), Canton $\times$ municipality FE are applied, and the Regulation coefficient can no longer be identified due to collinearity. In all specifications, population weights are applied to account for the fact that municipalities differ in their population. The numbers in parentheses show the standard errors, clustered at the municipal level. ${ }^{*} p<0.10,{ }^{* *} p<0.05,{ }^{* * *} p<0.01$ 


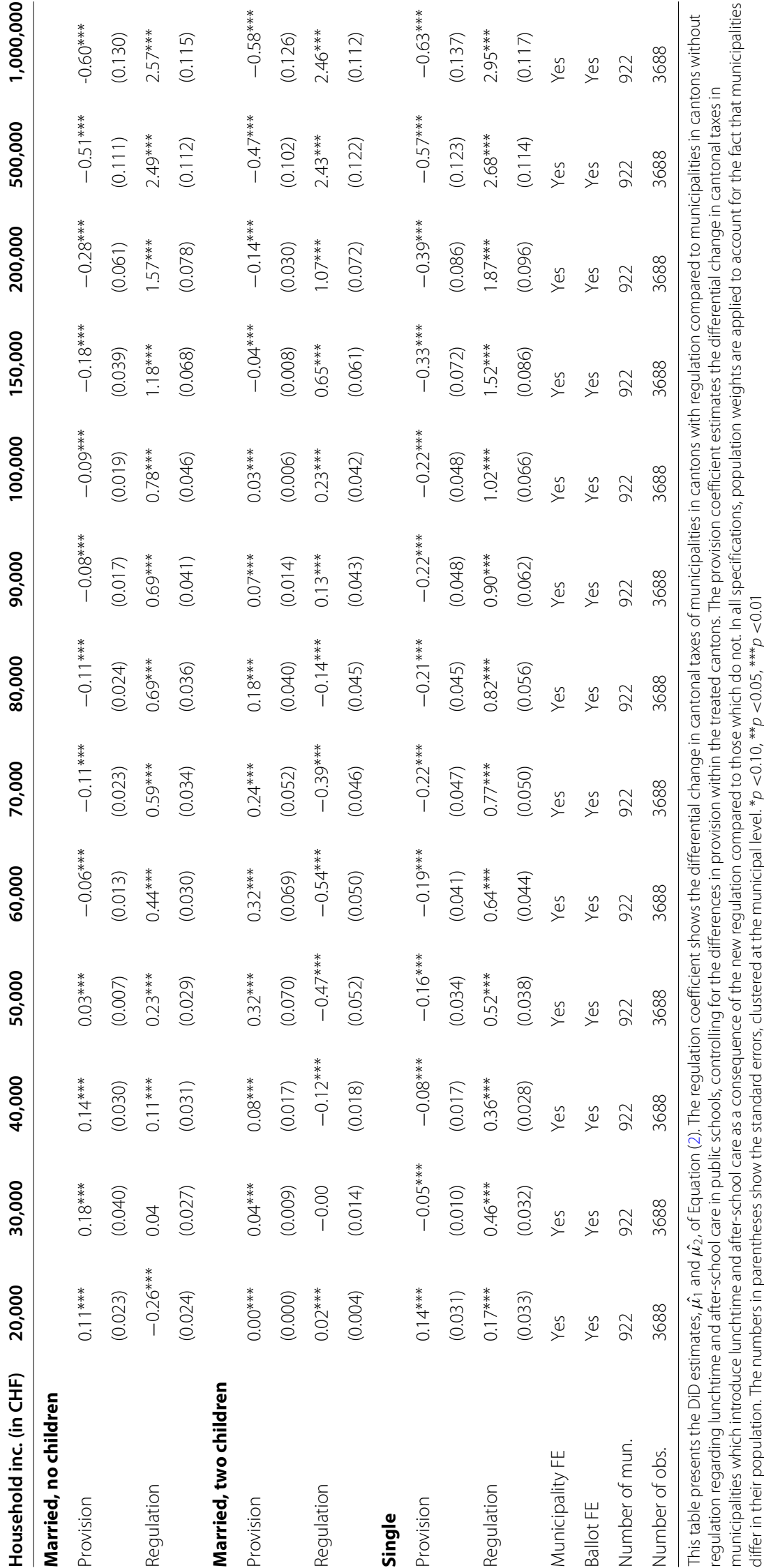




\section{Descriptives for municipalities in the canton of Bern}

Table 13 Descriptive statistics for municipalities with the canton of Bern only

\begin{tabular}{|c|c|c|c|c|c|c|c|c|}
\hline & \multicolumn{2}{|c|}{ Mat. leave I } & \multicolumn{2}{|c|}{ Mat. leave II } & \multicolumn{2}{|c|}{ Family policy } & \multicolumn{2}{|c|}{ Family init. } \\
\hline & Mean & SD & Mean & SD & Mean & SD & Mean & SD \\
\hline \multicolumn{9}{|l|}{ No provision } \\
\hline Share of Yes votes & 29.06 & $(12.55)$ & 44.51 & (11.59) & 38.74 & $(11.65)$ & 44.48 & $(8.75)$ \\
\hline Tax multiplier & 2.59 & $(0.23)$ & 1.80 & $(0.22)$ & 1.73 & $(0.20)$ & 1.73 & $(0.20)$ \\
\hline Share of SPP voters & 46.63 & (13.34) & 46.37 & $(12.81)$ & 43.42 & (11.19) & 43.42 & (11.19) \\
\hline Share of SP voters & 19.24 & $(8.43)$ & 18.93 & $(8.26)$ & 12.23 & $(5.83)$ & 12.23 & $(5.83)$ \\
\hline Voter turnout & 45.47 & $(8.33)$ & 48.74 & (7.19) & 42.36 & $(6.28)$ & 54.92 & (10.89) \\
\hline Births in $\%$ of pop & 1.08 & $(0.47)$ & 4.80 & $(1.23)$ & 12.95 & $(2.78)$ & 12.95 & (2.78) \\
\hline Deaths in $\%$ of pop & 1.00 & $(0.56)$ & 4.50 & $(1.27)$ & 12.49 & (3.13) & 12.49 & (3.13) \\
\hline Immigrants in \% of pop & 6.16 & $(2.63)$ & 30.74 & $(8.94)$ & 88.26 & (20.38) & 88.26 & (20.38) \\
\hline Emigrants in $\%$ of pop & 6.35 & $(2.34)$ & 30.43 & $(7.87)$ & 87.55 & $(19.76)$ & 87.55 & (19.76) \\
\hline Population in 1000 & 0.87 & $(0.85)$ & 0.88 & $(0.85)$ & 0.90 & $(0.87)$ & 0.90 & $(0.87)$ \\
\hline Number of mun. & 200 & & 200 & & 199 & & 199 & \\
\hline \multicolumn{9}{|l|}{ Cost $>$ median } \\
\hline Share of Yes votes & 33.19 & (11.30) & 51.88 & $(11.22)$ & 44.07 & $(11.25)$ & 51.47 & $(9.07)$ \\
\hline Tax multiplier & 2.44 & $(0.28)$ & 1.71 & $(0.23)$ & 1.63 & $(0.21)$ & 1.63 & $(0.21)$ \\
\hline Share of SPP voters & 35.29 & $(14.67)$ & 35.71 & (13.74) & 33.88 & $(11.01)$ & 33.88 & (11.01) \\
\hline Share of SP voters & 23.17 & $(7.40)$ & 23.82 & $(7.76)$ & 16.04 & $(5.84)$ & 16.04 & $(5.84)$ \\
\hline Voter turnout & 46.99 & $(5.75)$ & 51.58 & $(5.61)$ & 43.13 & $(5.23)$ & 54.57 & $(8.67)$ \\
\hline Births in $\%$ of pop & 1.02 & $(0.28)$ & 4.57 & $(0.97)$ & 11.92 & $(2.45)$ & 11.92 & $(2.45)$ \\
\hline Deaths in $\%$ of pop & 0.89 & $(0.35)$ & 4.24 & $(1.05)$ & 11.20 & (3.08) & 11.20 & (3.08) \\
\hline Immigrants in \% of pop & 6.31 & $(1.45)$ & 33.21 & $(6.25)$ & 90.15 & $(18.42)$ & 90.15 & (18.42) \\
\hline Emigrants in $\%$ of pop & 6.46 & $(1.61)$ & 31.42 & $(5.59)$ & 83.35 & $(16.70)$ & 83.35 & (16.70) \\
\hline Population in 1000 & 2.85 & $(2.48)$ & 2.91 & $(2.53)$ & 3.10 & $(2.67)$ & 3.10 & $(2.67)$ \\
\hline Number of mun. & 57 & & 57 & & 57 & & 57 & \\
\hline \multicolumn{9}{|l|}{ Cost $\leq$ median } \\
\hline Share of Yes votes & 30.35 & $(7.68)$ & 48.89 & $(8.18)$ & 42.96 & $(8.04)$ & 50.57 & $(7.00)$ \\
\hline Tax multiplier & 2.56 & $(0.19)$ & 1.77 & $(0.19)$ & 1.68 & $(0.18)$ & 1.68 & $(0.18)$ \\
\hline Share of SPP voters & 35.09 & $(9.69)$ & 35.85 & $(8.87)$ & 35.18 & $(7.42)$ & 35.18 & $(7.42)$ \\
\hline Share of SP voters & 24.54 & $(6.23)$ & 25.66 & $(6.22)$ & 16.23 & (5.19) & 16.23 & (5.19) \\
\hline Voter turnout & 45.37 & $(5.03)$ & 49.79 & $(4.95)$ & 42.03 & $(5.35)$ & 51.85 & $(7.01)$ \\
\hline Births in $\%$ of pop & 1.03 & $(0.25)$ & 4.71 & $(0.71)$ & 12.05 & $(2.16)$ & 12.05 & $(2.16)$ \\
\hline Deaths in $\%$ of pop & 0.95 & $(0.28)$ & 4.53 & $(1.04)$ & 11.70 & $(2.95)$ & 11.70 & $(2.95)$ \\
\hline Immigrants in \% of pop & 7.04 & $(2.45)$ & 34.71 & $(9.52)$ & 94.36 & $(20.86)$ & 94.36 & (20.86) \\
\hline Emigrants in \% of pop & 6.89 & $(2.89)$ & 32.76 & $(8.85)$ & 87.94 & (19.90) & 87.94 & (19.90) \\
\hline Population in 1000 & 3.78 & $(6.48)$ & 3.84 & $(6.47)$ & 4.08 & $(7.03)$ & 4.08 & (7.03) \\
\hline Number of mun. & 58 & & 58 & & 58 & & 58 & \\
\hline
\end{tabular}

This table shows descriptive statistics for municipalities in the canton of Bern included in the analyses. It distinguishes between municipalities with no provision, municipalities with provision and costs above median costs, and municipalities with provision and costs smaller or equal to median costs. Here, costs refer to per capita costs of lunchtime and after-school care after parental contributions and after redistribution between municipalities 


\section{Acknowledgements}

I am grateful to Aline Bütikofer, Matthias Krapf, Volker Grossmann, Marcus Roller, Kurt Schmidheiny, Michaela Slotwinski, Tim Wyndham, and Conny Wunsch and two anonymous referees for helpful comments, for helpful comments, and conference participants at the SSES Lausanne and at the IIPF Tampere, as well as participants of the brown bag seminars at the University of Basel and the Norwegian School of Economics (NHH). I am also grateful to Ruth Bieri and Miriam Kull from the department of education of the canton of Bern.

\section{Authors' contributions}

I am responsible for the entirety of this study. The author read and approved the final manuscript.

\section{Funding}

This study was conducted while under employment at the University of Basel. No other funding was received.

\section{Availability of data and materials}

Data on vote outcomes and municipality characteristics are freely available on the website of the Swiss Federal Statistical Office.

Vote outcomes: https://www.bfs.admin.ch/asset/de/px-x1703030000_101

Election National Council: https://www.pxweb.bfs.admin.ch/pxweb/ de/px-x-1702020000_105

Population: https://www.pxweb.bfs.admin.ch/pxweb/de/px-x0102020000_201

Data on income tax rates was provided by Parchet (2014).

Data on the provision of lunchtime and after-school care for the canton of Zurich used to be freely available on the website of the cantonal statistical office. The data was downloaded on 22 November 2016 from the website of the cantonal statistical office and for the years 2004 to 2013. However, when last checked, the data was no longer publicly available. I am happy to share the data with any interested party.

For the canton of Bern, data on the provision of lunchtime and after-school care was kindly provided by the cantonal department of education (Erziehungsdepartement Bern) and can be requested with them Data on facilities receiving financial assistance through the federal impulse program implemented to create more childcare places. These data are freely available on the webpage of the Federal Social Insurance Office. The data are only available on the German, French, or Italian version of the page, not on the English version.https://www.bsv.admin.ch/bsv/de/home/finanzhilfen/ kinderbetreuung.html.

The datasets used and analyzed for this study are available from the author on reasonable request. This excludes data on the provision of lunchtime and after-school care for the canton of Bern, for which the cantonal department of education must be contacted directly.

\section{Competing interests}

I declare that I have no competing interests.

\section{Received: 10 December 2019 Accepted: 29 September 2020}

Published online: 23 October 2020

\section{References}

Adda, J., Dustmann, C., Stevens, K. (2017). The career costs of children. Journal of Political Economy, 125(2), 293-337.

Alesina, A., Giuliano, P., Nunn, N. (2013). On the origins of gender roles: Women and the plough. The Quarterly Journal of Economics, 128(2), 469-530.

Angelov, N., Johansson, P., Lindahl, E. (2016). Parenthood and the gender gap in pay. Journal of Labor Economics, 34(3), 545-579.

Bauernschuster, S., \& Rainer, H. (2012). Political regimes and the family: How sex-role attitudes continue to differ in reunified Germany. Journal of Population Economics, 25(1), 5-27.

Bertrand, M., Goldin, C., Katz, L.F. (2010). Dynamics of the gender gap for young professionals in the financial and corporate sectors. American Economic Journal: Applied Economics, 2(3), 228-55.

Bowles, S. (1998). Endogenous preferences: The cultural consequences of markets and other economic institutions. Journal of Economic Literature, 36(1), 75-111.
Budig, M.J., \& England, P. (2001). The wage penalty for motherhood. American Sociological Review, 66(2), 204-225.

Bussey, K., \& Bandura, A. (1999). Social cognitive theory of gender development and differentiation. Psychological Review, 106(4), 676.

Bütikofer, A., Jensen, S., Salvanes, K.G., et al (2018). The role of parenthood on the gender gap among top earners. European Economic Review, 109, 103-123

Cislaghi, B., \& Heise, L. (2020). Gender norms and social norms: Differences, similarities and why they matter in prevention science. Sociology of Health \& Illness, 42(2), 407-422.

Cormon, P. (2014). Swiss politics for complete beginners, (p. 24). Geneva: Slatkine.

Correll, S.J., Benard, S., Paik, I. (2007). Getting a job: Is there a motherhood penalty? American Journal of Sociology, 112(5), 1297-1338.

Felfe, C. (2012). The motherhood wage gap: What about job amenities? Labour Economics, 19(1), 59-67.

Felfe, C., Lechner, M., Thiemann, P. (2016). After-school care and parents' labor supply. Labour Economics, 42, 64-75.

Fitzenberger, B., Sommerfeld, K., Steffes, S. (2013). Causal effects on employment after first birth-A dynamic treatment approach. Labour Economics, 25, 49-62.

Girsberger, E.M., Hassani-Nezhad, L., Karunanethy, K., Lalive, R. (2019). Mothers at Work in Switzerland: Impact of First Paid Maternity Leave on Mothers' Employment and Earnings. Mimeo University of Lausanne.

Giuliano, P. (2017). Gender: A historical perspective. In S.L. Averett, L.M. Argys, S.D. Hoffman (Eds.), The Oxford Handbook of Women and the Economy (pp. 1-32). New York, NY: Oxford University Press.

Goldin, C. (2014). A grand gender convergence: Its last chapter. American Economic Review, 104(4), 1091-1119.

Kleven, H., Landais, C., Posch, J., Steinhauer, A., Zweimüller, J. (2019). Child penalties across countries: Evidence and explanations. AEA Papers \& Proceedings, 109, 122-26.

Kleven, H., Landais, C., Søgaard, J.E. (2019). Children and gender inequality: Evidence from Denmark. American Economic Journal: Applied Economics, 11(4), 181-209.

Koseki, S.A. (2017). Moral matrices: Space through the unfolding of direct democracy in switzerland. PhD thesis, Ecole Polytechnique Fédérale de Lausanne.

Kotsadam, A., \& Finseraas, H. (2011). The state intervenes in the battle of the sexes: Causal effects of paternity leave. Social Science Research, 40(6), 1611-1622.

Linder, W. (2010). Swiss democracy: possible solutions to conflict in multicultural societies: Springer.

Olivetti, C., \& Petrongolo, B. (2017). The economic consequences of family policies: Lessons from a century of legislation in high-income countries. Journal of Economic Perspectives, 31(1), 205-30.

Parchet, R. (2014). Are local tax rates strategic complements or strategic substitutes? Università della svizzera italiana.

Paull, G. (2008). Children and women's hours of work. The Economic Journal, 118(526), 8-27.

Slotwinski, M., \& Stutzer, A. (2018). Women leaving the playpen: The emancipating role of female suffrage. CESifo Group Munich No. 7002.

Slotwinski, M., \& Stutzer, A. (2019). The deterrent effect of an anti-minaret vote on foreigners' location choices. Journal of Population Economics, 32(3), 1043-1095.

Steinhauer, A. (2018). Working moms, childlessness, and female identity. CEPR Discussion Papers 12929.

Stutzer, A., \& Lalive, R. (2004). The role of social work norms in job searching and subjective well-being. Journal of the European Economic Association, 2(4), 696-719.

Teso, E. (2019). The long-lerm effect of demographic shocks on the evolution of gender roles: Evidence from the transatlantic slave trade. Journal of the European Economic Association, 17(2), 497-534.

Unterhofer, U., \& Wrohlich, K. (2017). Fathers, parental leave and gender norms. DIW Berlin Discussion Paper No. 1657

Waldfogel, J. (1998). Understanding the "family gap" in pay for women with children. Journal of Economic Perspectives, 12(1), 137-156.

\section{Publisher's Note}

Springer Nature remains neutral with regard to jurisdictional claims in published maps and institutional affiliations. 